\title{
The Effect of Managerial Share Pledges on the Cost of Debt
}

\author{
Soonhong Park, Professor, Chungnam National University \\ Hyeon Sook Kim, Researcher, Public Procurement Service \\ Byungkwon Lim ${ }^{* *}$, Research Fellow, IBK Economic Research Institute
}

\begin{abstract}
$\langle$ Abstract〉
We examines whether share pledges by controlling shareholders influence a firm's cost of debt. We also investigate whether the relationship between share pledges and the cost of debt stems from the managerial risk-taking incentives or pursuing the private benefits of controlling shareholders. We make three major findings. First, we find the cost of debt is higher in firms with share pledges than in firms without share pledges. Furthermore, we identify a positive relationship between the cost of debt and the level of share pledges. Second, we find that there is no increased corporate financial leverage or investment activities in firms with share pledges. Finally, our empirical evidence demonstrates that the positive relationship between share pledges and cost of debt is more pronounced for lower foreign institutional investor stakes or higher controlling shareholders ownership. Overall, the results indicate that share pledges by controlling shareholders negatively affect the cost of debt. However, the effect of share pledges on the cost of debt is differently influenced by a firm's ownership structure. Our findings suggest that share pledges induce stockholder-bondholder conflict, and the bondholder requires more risk premium due to the decrease of firm value.
\end{abstract}

Keywords: Share Pledges; Cost of Debt; Risk-Taking Incentives; Agency Problem; Credit Rating

JEL Classification: G12, G32, G34

* This research was supported by Research Grant Program from the Korean Securities Association and FnGuide in 2020.

** Corresponding Author. Address: IBK Economic Research Institute, Industrial Bank of Korea, 79 Eul-ji ro Jung-go, Seoul, Korea, 04541; E-mail: lim@gmail.com; Tel: +82-2-729-6859; Fax: +82-505-076-2610

Received: March 4, 2021; Revised: June 15, 2021; Accepted: June 24, 2021 


\title{
경영자의 주식담보대출이 타인자본비용에 미치는 영향*
}

\author{
박 순 홍 (충남대학교 교수) \\ 김 현 숙 (조달청 연구원) \\ 임 병 권 (IBK 경제연구소 연구위원)**
}

\begin{abstract}
본 연구는 대주주의 주식담보대출이 타인자본비용과 관련성이 존재하는지 검증하였다. 또한, 주식담보대출이 타인자본비용에 미치는 영향이 경영자의 위험추구나 지배주주의 사익추구 중에서 어떠한 요인에 기인하는지를 분석하였다. 본 연구의 주요 분석 결과는 다음과 같다. 첫째, 대주주가 주식담보대출을 받는 기업은 타인자본비용이 높게 나타나며 주식담보대출 수준이 높을수록 타인자본 비용은 증가하였다. 둘째, 주식담보대출 기업은 재무레버리지나 투자활동이 증가하지 않아 경영자의 위험추구 행위는 확인되지 않았다. 셋째, 주식담보대출 기업 중에서도 대체로 외국인투자자의 지분율이 높으면 타인자본비용이 더 낮으나. 최대주주 지분율이 높으면 타인자본비용은 보다 높게 나타났다. 전체적으로, 대주주의 주식담보대출은 타인자본비용에 부정적인 영향을 미치고 있다. 특히 외국인 투자자의 지분이 높아 외부 감시인으로서 대리인 문제를 완화할 수 있는 기업은 타인자본비용이 낮게 나타나나, 경영자의 사익추구 환경이 용이한 기업은 주식담보대출이 타인자본비용을 증가시키고 있다. 즉, 대주주의 주식담보대출은 채권자와도 대리인 문제를 야기할 수 있으며, 기업가치 하락에 따라 채권자는 더 높은 위험 프리미엄을 요구하고 있음을 추론해 볼 수 있다.
\end{abstract}

핵심 단어 : 주식담보대출, 타인자본비용, 위험추구 유인, 대리인 문제, 신용등급

JEL 분류기호: G12, G32, G34

\footnotetext{
* 본 연구는 2020년 한국증권학회-FnGuide 연구지원사업으로 수행되었으며, FnGuide 자료를 사용 하였습니다. 본 연구는 저자들의 개인적인 의견일 뿐 소속기관의 견해와 무관합니다.

** 연락담당 저자. 주소: 서울특별시 중구 을지로 $79, \mathrm{IBK}$ 기업은행 경제연구소, 04541; E-mail: lim@gmail.com; 02-729-6859; Fax: 0505-076-2610.
} 


\section{1. 서론}

본 연구는 대주주나 임원 등에서 그들이 보유한 주식을 이용한 차입의사결정(이하 주식담보 대출)이 채권자와 이해상충(conflict of interest)을 야기하는지에 대해 고찰하고자 한다. 이를 위해 주식담보대출이 타인자본비용(cost of debt)에 어떠한 영향을 미치는지를 다양한 측면에서 분석하고 관련 시사점을 제시하고자 한다.

주식담보대출은 대주주 등이 보유한 주식의 일부 또는 전부를 금융기관에 담보로 맡기고 개인적인 사유로 자금을 차입하는 수단이다. 주식담보대출은 보유 주식에 대한 의결권을 행사하는데 제한을 받지 않으며, 개인적인 유동성 제약을 완화할 수 있어 다수의 기업에서 널리 활용되고 있다.1) 여기서 대주주의 주식담보대출은 개인적인 차입행태이므로 해당 기업의 배당정책이나 재무정책 또는 기업가치에 어떠한 영향을 미치지 않으리라고 예상해 볼 수 있다.

하지만, 대주주가 주식담보대출을 받는 기업은 주가하락 시 야기될 수 있는 반대매매를 방어하기 위한 수단으로 자사주를 매입하거나 배당을 증가시키며(Chan et al., 2018; Cho and Yang, 2019) 이익을 상향조정 한다는 결과가 제시되고 있다(Dejong et al., 2020; Noh, 2019; Xu, 2021).2) 또한, 주식담보대출은 부정적인 공시효과와 향후 경영성과의 악화와 함께(Chen et al., 2007; Cho and Yang, 2019; Dou et al., 2019; Kao et al., 2004; Singh, 2018; Wang and Chou, 2018), 대출기관의 반대매매로 인한 우발위험에 노출되어 주식수익률의 변동성도 심화된다는 결과도 보여주고 있다(Anderson and Puleo, 2020; Lim and Park, 2019).3) 따라서 대주주의 주식담보대출은 기존 주주와의 대리인 문제(agency problem)를 야기할 개연성이 있다.

한편, 대주주의 주식담보대출은 주주 측면과 아울러 채권자에게도 영향을 미칠 수 있으며, 경영자의 위험추구(risk-taking) 관점에서 채권자에게 부정적 또는 긍정적 영향을 미칠 가능성이 모두 공존한다.4) 우선, 대주주는 대출로 조달한 재원을 개인적으로 소비하거나 여타 자산에 투자할 수 있다. 그런데 특정 자산에 투자하는 경우 미래 투자성과에 불확실성이 존재한다.

1) 국내 업체의 조사에 따르면 2018년 기준 자산 5 조 원 이상 60 대 그룹 총수 중에서 22 개 그룹 총수(29.6\%)가 주식담보대출을 행한 것으로 나타났다(주요 그룹 총수 22 명 보유 주식 $30 \%$ 담보로 잡혀, 한국경제, 2019.01.06., https://www.hankyung.com/economy/article/201901065019Y).

2) 대주주 등이 보유한 주식을 담보로 한 담보인정비율(loan-to-value)은 국가별로 차이가 있다. 미국은 대체로 계약일의 시장가격 대비 50 80\% 수준으로 대출이 이루어지며, 국내시장은 대출 기관별로 차이가 있으나 미국과 유사한 수준인 것으로 알려져 있다(Lim and Park, 2019).

3) 주식담보대출에 관한 다수 연구들은 부정적인 효과를 제시하나 반대의 결과도 존재한다. $\mathrm{Li}$ et al.(2019)의 중국 시장(상해 및 선전)을 대상으로 한 분석에 의하면, 주식담보대출과 토빈의 $\mathrm{Q}$ 는 유의적인 양(+)의 관련성을 보이나 주가급락위험(crash risk)과는 관련성이 낮아 해당 기업의 가치는 증가한다는 결과를 제시하고 있다. 즉, 주식담보대출이 기존 주주에게는 부정적인 영향을 미쳐 자기자본비용을 증가시키나, 채권자에게는 긍정적인 영향을 미쳐 타인자본비용이 감소하고 이로 인해 전반적인 기업가치는 증대될 가능성도 있다. 본 연구의 주요 목적은 주식담보대출에 따른 타인자본비용의 영향을 고찰하는 것이므로 해당 내용에 대해서는 추후 고찰해 볼 필요성이 있다.

4) 본 연구에서 채권자는 대주주 개인에게 주식담보대출을 해준 금융기관이 아닌 기업에서 발행하는 채권을 보유하거나 잠재적으로 보유하게 될 채권자를 의미한다. 
The Effect of Managerial Share Pledges on the Cost of Debt

따라서 전체적인 투자 포트폴리오의 수익률 관리를 위해 그들은 소속 기업의 성과를 극대화할 목적으로 과도하게 위험을 추구할 개연성이 있다(Anderson and Puleo, 2020; Puleo et al., 2021). 즉, 재무 레버리지를 급격하게 증가시키거나 보다 위험한 투자안을 실행함으로써 채권자 와의 이해 상충이 야기될 수 있으며, 이로 인해 타인자본비용이 증가할 가능성이 있다.5)

반면, 주식담보대출은 대주주의 위험추구를 낮추는 방향으로 작용할 가능성도 있다. 주식담보 대출은 급격한 주가 하락 시 우발적 위험(contingency risk)인 마진콜에 직면한다. 만약, 주가가 담보인정비율 이하로 하락하면 대출기관은 주식담보대출을 받은 대주주에게 추가적인 증거금을 요구하게 된다. 그런데 대주주가 유동성이 부족하면 보유 주식을 매각하는 등의 방법으로 자금을 마련해야 하며, 추가증거금을 납부하지 못하면 반대매매에 직면할 수 있다. 즉, 반대매매 시 보유 지분이 감소하여 기업의 지배력이 약화하며 대규모 매도로 인해 추가로 주가가 하락할 수 있다(Aboody and Lev, 2000; Fernandes and Ferreira, 2009; Puleo et al., 2021). 따라서 경영자는 더욱 안전한 투자안을 선택함으로써 위험을 회피하고자 할 것이며 기업의 위험 감소에 따라 타인자본비용이 감소할 개연성도 있다.6)

이상과 같이 대주주의 주식담보대출이 채권자에게 영향을 미칠 개연성이 높음에도 불구하고 국내는 관련 연구가 전무하며, 해외시장은 비교적 최근에 직접적인 분석이 이루진 상황이다.7) 중국 시장의 경우 대주주의 주식담보대출은 기업가치에 부정적인 영향을 미침으로써 타인자본 비용이 증가한다는 결과를 제시하고 있다(Ouyang et al., 2018). 반면, 미국 시장에서는 대주주의 주식담보대출이 경영자의 위험추구 유인을 억제하는 동인으로 작용하여 타인자본비용이 감소 한다는 상반된 결과를 보여주고 있다(Puleo et al., 2021). 즉, 국내시장에서 대주주의 주식담보 대출이 타인자본비용에 어떠한 영향을 미치는지를 엄정하게 고찰해 볼 필요성이 있다.

본 연구는 2009년부터 2018년까지의 기간을 대상으로 유가증권 및 코스닥시장에 상장된 기업들의 주식담보대출 내역을 이용하여 타인자본비용과의 관련성을 분석하고자 한다. 이를 위해 대주주의 주식담보대출 여부에 따라 대응 표본(matching sample)을 구성한 후 상호 비교·분석하고자 한다. 보다 구체적인 연구의 목적은 다음과 같다. 첫째, 대주주의 주식담보대출 여부 및 총 발행주식 대비 대주주 전체의 주식담보대출 비율, 대주주 개인별 보유 주식 대비 주식담보대출 수준이 타인자본비용의 대용치인 회계 측면의 이자비용(사후적)과 신용등급 (사전적)에 어떠한 영향을 미치는지는 분석하고자 한다. 둘째, 주식담보대출이 타인자본비용에

5) 기업의 경영위험 관점에서도 주식담보대출은 채권자에게 영향을 미칠 수 있다. 주가의 급락으로 인해 추가증거금을 납부하지 못해 반대매매가 이루어지면 대주주는 보유 지분이 감소하여 경영권을 상실할 수 있다. 따라서 지배주주가 변경되는 경우 기존의 경영전략 등 전반적인 경영환경이 변화될 수 있으며 구조조정 등이 발생할 수 있고, 이에 따라 경영위험이 증가하여 채권자에게 부정적인 영향을 미칠 수도 있다(Ouyang et al., 2018).

6) 채권자가 투자안을 적극적으로 모니터링함으로써 투자 효율성이 증대되고 경영자의 위험선호 유인을 제어할 가능성도 존재한다(Meng et al., 2019).

7) 예외적으로 Chen et al.(2007)은 주식담보대출이 타인자본비용에 영향을 미칠 가능성을 제시하고 있으며, Chen and $\mathrm{KaO}(2011)$ 는 대주주의 주식담보대출과 채권자 은행의 수익성 간 관련성을 분석함으로써 채권자 부의 손실 가능성을 제기하고 있다. 
한국증권학회지 제50권 6호 (2021)

영향을 미친다면 경영자의 과도한 위험추구 측면 또는 대주주의 사익 추구 측면 중에서 주로 어떠한 요인에 기인하는지를 고찰하고 관련 시사점을 제시하고자 한다.8) 본 연구는 대주주의 주식담보대출이 채권자에게 어떠한 영향을 미치는지 그리고 해당 원인이 어떠한 측면에 기인하는지를 규명한다는 점에서 이론적으로 중요한 의의가 있다.

본 연구의 주요 분석 결과는 다음과 같다. 첫째, 대주주의 주식담보대출 내역이 존재하는 기업은 대응 표본보다 타인자본비용(회계 또는 신용등급 측면)이 유의적으로 높게 나타난다. 또한, 기업의 총 발행주식 대비 대주주의 주식담보대출 비중이 높거나 개인별 보유 주식 대비 주식담보대출 수준이 높을수록 타인자본비용은 증가한다. 둘째, 대주주의 주식담보대출 기업은 대응 표본보다 재무레버리지(부채비율) 또는 연구개발비 지출이 감소하여 주식담보대출로 인한 타인자본비용의 증가는 경영자의 과도한 위험추구로 인해 발생하지는 않음이 확인된다. 셋째, 대주주의 주식담보대출에도 불구하고 대체로 외국인투자자의 지분 수준이 높을수록 타인자본 비용이 더 낮게 나타난다. 반면, 최대주주의 지분이 높아 대주주의 사익추구 환경이 용이한 기업에서는 대주주의 주식담보대출 시 타인자본비용이 증가하고 있다.

이하 본 논문은 다음과 같이 구성된다. 제 2장에서는 기존 연구를 살펴보고, 제 3 장에서는 연구의 내용 및 분석 방법에 대해 설명한다. 그리고 제 4장에서는 실증분석 결과를 제시하고 마지막 제 5 장 결론에서는 연구 결과를 요약하고 시사점을 제시한다.

\section{2. 기존연구}

전통적으로 대주주 등의 주식담보대출은 개인의 유동성 제고 차원에서 이루어지는 의사결정 으로 인식되었다. 하지만, 해외시장에서 주식담보대출은 대리인 문제를 야기함으로써 주주나 채권자에게 영향을 미친다는 실증적 증거가 제시되고 있다.

이와 같은 주식담보대출은 관련 자료의 이용이 불가능하여 주로 데이터 확보가 가능한 대만 시장을 중심으로만 연구가 진행되었으나(Chan et al., 2018; Chen et al., 2007; Dou et al., 2019; Kao et al., 2004; Wang and Chou, 2018), 2000년대 후반부터 시행된 주식담보대출 관련 공시 규정이 의무화되며 비교적 뒤늦게 해당 분야의 연구가 활성화되고 있다.9)

주식담보대출을 받은 대주주는 보유 주식을 담보로 자금만을 차입할 뿐이며, 담보로 제공한 주식에 대해서도 여전히 의결권을 유지할 수 있다는 이점이 존재한다. 주식담보대출을 행하는 경우 일반적으로 주가의 50 80\%가량을 담보가치로 인정받으며 향후 주가가 담보가치 이하로

8) 경영자의 과도한 위험추구 행위는 전반적인 기업 위험을 증대시켜 대리인 문제를 야기할 수 있다. 그리고 기업의 재무적 불투명성 또는 정보비대칭이 높은 등 지배구조가 좋지 않은 기업에서는 대주주의 사익추구 환경이 보다 용이할 수 있어 대리인 문제가 심화할 가능성이 있다. 한편, 대주주의 사익추구 환경이 용이한 기업의 경우 기업가치가 하락할 수 있으며, 이로 인해 채권자는 보다 높은 수익률을 요구할 가능성이 있다.

9) 우리나라는 2009년 자본시장통합법이 시행되며 대주주 등의 주식담보대출에 대한 공시가 의무화 되었고, 미국은 2010년 도드-프랭크 금융개혁법(Dodd-Frank Wall Street Reform and Consumer Protection Act)이 시행되며 주식담보대출 내역을 공시하도록 제도화하였다(Lim and Park, 2019). 
The Effect of Managerial Share Pledges on the Cost of Debt

하회하면 대출기관으로부터 추가적인 담보(마진콜)를 요구받는다. 그리고 이를 이행하지 못하는 경우 반대매매가 이루어질 수 있어 주식담보대출을 받은 내부자는 그들의 보유 지분이 감소할 수 있다. 즉, 주식담보대출은 소유권(cash flow rights)을 대출기관에 이전한 채로 지배권(control rights)은 유지할 수 있어 대주주의 사익추구를 위한 수단으로 악용할 개연성이 있다.

기존 연구들은 주로 대주주의 주식담보대출이 여타 주주와 대리인 문제를 일으키는지에 대해 주가 성과나 기업가치 그리고 위험 측면에서 검증하고 있다. 대주주의 주식담보대출과 기업가치의 관련성은 대만 시장뿐만 아니라 미국, 인도 등에서도 기업가치에 부정적인 영향을 미친다는 결과가 제시되고 있으며(Chen et al., 2007; Kao et al., 2004; Singh, 2018), 주가변동성이 확대됨에 따라 기업의 위험이 증가한다는 결과도 보여주고 있다(Anderson and Puleo, 2020).10) 또한, 대주주의 주식담보대출에 대한 공시효과도 일관적으로 음(-)으로 나타나며(Dou et al., 2019), 주식담보대출과 관련된 자사주 매입은 공시일의 시장 반응이 부정적이라는 결과도 제시 되고 있다(Chan et al., 2018). 따라서 대주주의 주식담보대출은 기존 주주와 이해 상충을 야기함으로써 그들의 부에 부정적인 영향을 미칠 가능성이 있다.

한편, 본 연구와 관련된 주식담보대출과 채권자 간의 이해 상충은 제한적으로 연구가 진행된 상황이다. Chen et al.(2007)은 지배주주의 주식담보대출이 소액주주나 채권자에 미치는 영향에 대해 분석하였는데, 지배주주는 주식담보대출을 통해 사익을 획득 가능하며 기업과 관련된 위험은 소액주주로 이전이 가능하다는 결과를 제시하고 있다. 즉, 소유-지배 괴리 하에서 실행되는 지배주주의 주식담보대출은 대리인 문제를 야기할 수 있음을 시사하고 있다. 그리고 Ouyang et al.(2018)과 Puleo et al.(2021)은 주식담보대출이 채권자에 어떠한 영향을 미치는지를 직접적으로 검증하였는데, 상반된 연구 결과를 제시하고 있다.

우선, Ouyang et al.(2018)은 중국 시장을 대상으로 주식담보대출이 해당 기업의 채권수익률에 어떠한 영향을 미치는지에 대해 분석하였다. 분석 결과에 의하면, 주식담보대출이 존재하는 기업에서는 신규로 채권을 발행할 때 채권수익률 스프레드가 증가하여 타인자본비용이 증가 한다는 결과를 보였다. 즉, 주식담보대출이 존재하는 기업의 경우 마진콜과 같은 우발적 위험에 노출되며, 정보비대칭이 증가할 수 있으므로 채권자들은 더 높은 수익률을 요구할 수 있음을 시사하고 있다. 그러나 미국 시장을 대상으로 한 연구에서는 반대의 결과를 제시하고 있다. Puleo et al.(2021)은 주식담보대출과 타인자본비용의 관련성에 대해 공시효과 및 대응 표본과 비교·분석하였다. 분석 결과에 의하면, 대주주의 주식담보대출 공시효과와 채권수익률은 음(-)의 관계를 가지며(주식담보대출 비율에 따른 공시일 이전과 이후의 채권수익률 변화), 대응 표본 대비 주식담보대출 기업은 채권을 신규 발행할 때 수익률 스프레드가 감소한다는 결과를 제시하고 있다. 즉, 주식담보대출이 존재하는 기업의 경우 경영진은 우발위험을 대비하기 위해 더욱 위험

10) 대주주의 주식담보대출의 효과는 대체로 부정적이나 일부 연구는 상반된 결과를 제시하고 있다. Li et al.(2019)의 연구에서는 기업가치가 증대됨을 보여주고 있는데, 이는 특히 주식담보 대출금액을 주주 개인적으로 이용하지 않고 자사를 위해 재투자하는 경우에 강건한 결과가 나타났다. 이와 유사하게 Singh(2018)의 경우에도 재무적 제약 등이 존재하는 기업에서 대주주의 주식담보대출을 통해 기업 유동성을 개선시키는 경우 기업가치에 긍정적임을 제시하고 있다. 
한국증권학회지 제50권 6호 (2021)

회피적인 의사결정을 행할 수 있으며, 이로 인해 기업의 전반적인 위험이 감소하고 타인자본비용에 긍정적인 영향을 미칠 수 있음을 시사하고 있다. 즉, 대주주의 주식담보대출이 채권자에게 미치는 영향은 긍정적이거나 부정적일 가능성이 모두 공존하고 있다.

전술한 바와 같이 주식담보대출에 대해 해외시장에서는 다양한 측면에서 연구가 진행 중이나, 국내는 주로 주주 측면의 대리인 문제를 중심으로 제한된 연구만 진행된 상황이다. 대주주의 주식담보대출에 관한 국내의 연구는 다음과 같다.

우선, Cho and Yang(2019)은 주식담보대출의 공시효과 및 대주주의 주식담보대출로 인해 발생할 수 있는 기존 주주와의 대리인 문제가 기업의 배당정책에 영향을 미치는지를 분석하였다. 분석 결과에 의하면, 대주주의 주식담보대출에 따른 공시일의 주가 반응은 부정적으로 나타나며, 주가 하락에 따른 마진콜 발생 가능성을 미리 방지하기 위해 배당을 증가시킨다는 결과를 제시하고 있다. 즉, 소유권과 지배권을 분리할 수 있는 대주주의 주식담보대출은 대리인 문제를 심화시킴 으로써 여타 주주의 부를 감소시킬 수 있음을 제시하고 있다.

그리고 Lim and Park(2019)은 최대주주나 주요주주 등과 같은 기업 내부자의 주식담보대출이 주가급락위험을 증대시키는지에 대해 분석하였다. 분석 결과, 주식담보대출과 주가급락의 관련성은 시장별로 상이하게 나타났는데 코스닥시장 기업의 경우 주식담보대출이 주가급락위험에 유의적인 양 $(+)$ 의 영향을 미친다는 결과를 보고하고 있다. 그리고 코스닥시장 기업 중에서도 정보비대칭 수준이 높으며, 재무적 불투명성이 큰 기업에서 더욱 강건한 결과를 보여 주식담보 대출은 주주 간 대리인 문제를 심화시킴으로써 소액주주의 부를 침해할 수 있음을 제시하고 있다.

마지막으로 Noh(2019)는 대주주의 주식담보대출은 반대매매 압력에 직면할 가능성이 있으므로 경영자는 이익조정(earnings management)을 통해 주가를 부양할 동기가 있는지를 분석하였다. 분석 결과에 의하면, 경영자가 주식담보대출을 받은 기업의 경우 실물 활동 이익 조정과 유의한 관련성이 있는 것으로 나타났다. 즉, 경영자의 주식담보대출 비중이 높을수록 실물 활동을 통한 이익조정이 증가하여 경영자는 주가하락을 방어하기 위한 수단으로 이익을 상향조정 할 수 있다는 실증적 증거를 제시하고 있다.

이상과 같이 대주주의 주식담보대출 행위는 주주뿐만 아니라 채권자와도 대리인 문제를 초래함으로써 채권자에게 영향을 미칠 가능성이 있다. 따라서 국내시장의 경우에도 대주주 주식담보대출이 타인자본비용에 영향을 미치는지를 분석하고 해당 원인에 대해 엄정하게 검증해 볼 필요가 있다.

\section{3. 연구내용 및 방법}

\section{1 표본의 구성}

본 연구는 2009년부터 2018년까지의 기간에 대해 유가증권과 코스닥시장에 소속된 기업을 대상으로 한다. 분석대상 표본 선정에 있어 우선적으로 금융업종과 자본잠식 기업은 제외한다. 또한, 본 연구에 필요한 재무 자료가 없는 기업을 제외한 후 최종적으로 총 5,608 개(분석표본 
The Effect of Managerial Share Pledges on the Cost of Debt

및 대응 표본 각각 2,804개)의 기업-연간(firm-year)으로 자료를 구성하여 분석하고자 한다.

분석에 필요한 대주주와 임원 등의 연도별 주식담보대출 내역은 Fnguide의 Dataguide에서 제공하는 주식담보대출 자료를 이용한다. Dataguide는 대주주 개인별 주식담보대출 내역(주주명, 주식담보대출 계약일, 주식담보대출 계약수량, 보유 주식 대비 주식담보대출 비율, 총 발행주식 대비 주식담보대출 비율 등)에 대한 상세한 정보를 제공하고 있다. 따라서 해당 데이터베이스를 활용하여 본 연구에 필요한 자료를 추출-가공한 후 분석에 이용한다. 또한, 타인자본비용 추정을 위한 자료는 NICE 평가정보에서 제공하는 데이터베이스인 Kis-value에서 추출하여 이용하며, 국내의 3 대 신용평가기관(NICE, 한국신용평가, 한국기업평가)이 공표하는 회사채 신용등급 자료는 한국상장사협의회 데이터베이스(TS-2000)에서 제공하는 자료를 가공하여 사용한다. 추가로 분석에 필요한 주가 자료는 Fnguide의 Dataguide Pro에서 추출·가공하여 이용하며, 분석에 필요한 최대주주 및 특수관계인 등의 지분율 자료와 재무 자료는 TS-2000에서 추출하여 이용하고자 한다.

\section{2 연구방법}

\subsection{1 타인자본비용 추정}

기업의 타인자본비용은 외부자금을 사용하는 대가로 부담해야 하는 비용이다. 타인자본비용의 추정은 사후적 성격을 갖는 재무제표를 이용(부채조달비용, debt cost)하거나, 사전적 타인자본 비용의 대용치로 통용되는 기업의 신용등급을 이용할 수 있다(Francis et al., 2005; Lee et al., 2008; Pittman and Fortin, 2004).

여기서 신용평가기관에서 공표하는 신용등급은 재무 정보 등과 같은 정량적 자료뿐만 아니라 자산 또는 이익의 질과 같은 비(非)-재무적인 요인도 고려하여 기업의 채무불이행 위험을 측정하는 타인자본비용이라 볼 수 있다(Lee et al., 2008). 특히, 신용평가는 기업어음이나 채권을 발행할 때 활용되며 금융기관의 여신심사에 있어 금리 산정을 위한 참고자료로도 이용되고 있다(Yang et al., 2011). 즉, 신용등급은 회사채 발행금리에 직접적인 영향을 줄 수 있어 사전적 성격이 있으나, 회사채를 발행하지 않은 기업은 신용등급이 존재하지 않아 분석대상 표본이 제한될 수 있다.

전술한 신용등급의 한계점으로 인해 회계학 분야에서는 재무제표를 이용하여 다양한 방식으로 타인자본비용을 추정하고 있다. 따라서 본 연구는 회사채 신용등급뿐만 아니라 재무제표를 토대로 추정되는 대표적인 3가지 방식을 이용하고자 한다. 또한, 추가로 기업의 신용평점도 활용하여 연구 결과의 신뢰성을 높이고자 한다.

우선, 재무제표를 통해 타인자본비용을 추정하는 방법은 식 (1) 식 (3)과 같다.11) 식 (1)은 총 금융비용을 평균적인 이자발생부채로 나누어 타인자본비용을 추정하는 것이다(Ko and Lee, 2012;

11) 추가로 Park and Jung(2015)은 이자비용을 부채총액으로 나누어 타인자본비용을 계산하며, Ko and Lee(2012)는 Kis-value에서 제공하는 타인자본비용(식 (1)에서 실효세율을 반영)도 활용하고 있다. 한편, Park and $\operatorname{Kim}(2019)$ 은 식 (1)과 함께 3년 만기 국고채 이자율을 차감한 수치(차입이자율 스프레드)도 이용하고 있다. 따라서 전술한 방법 모두를 고려하였는데, 전체적으로 식 (1) 식 (3)을 이용한 분석과 대동소이한 결과를 보였다. 
한국증권학회지 제 50 권 6 호 (2021)

Oh et al., 2011). 여기서 총 금융비용은 손익계산서 상의 이자비용으로써 이자비용, 사채이자, 사채상환손익 및 건설자금이자를 반영한다. 그리고 이자발생부채는 단기차입금, 유동성장기부채 (기타유동성장기부채 차감), 단기사채, 장기사채, 장기차입금, 금융리스부채, 정리채무(중장기 차입금 등의 이자 발생 부채), 장단기유동화채무 등을 합산하고 기타 유동성 장기부채를 차감한 것이다.

$$
D C O S T 1=\frac{\text { 총금융비용 }}{\text { 평균이자발생부채 }}
$$


부채의 평균으로 나누어 계산하는 것이다(Francis et al., 2005; Lee et al., 2008; Yu, 2011). 여기서 세후이자비용은 이자비용에 법인세 절감 효과를 고려한 것이고, 장단기부채는 단기차입금, 장기차입금, 유동성장기부채, 사채를 포함한다.

$$
\operatorname{DCOST2}=\frac{\text { 세후이자비용 }}{\text { 장단기부채의 평균 }}
$$

마지막으로 식 (3)의 DCOST3은 이자비용과 사채이자의 합에 대해 총부채에서 이연부채를 차감한 금액으로 타인자본비용을 추정하는 것이다. 여기서 이연부채는 미래에 상환해야 할 채무가 아니라 수익 중에서 발생주의회계에 근거하여 당해 기간의 수익으로 인정할 수 없는 부분이므로 분모에서 제외해야 할 필요성이 있다(Kim and Kim, 2012).

$$
\operatorname{DCOST3}=\frac{\text { 이자비용 }+ \text { 사채이자 }}{[(\text { 기초총부채 }- \text { 기초이연부채 })+(\text { 기말총부채 }- \text { 기말이연부채 })] / 2}
$$

한편, 사전적 타인자본비용의 대용치는 회사채 신용등급과 기업 신용평점을 이용한다. 우선, 회사채 신용등급은 국내 3 대 신용평가사인 나이스신용평가와 한국신용평가, 그리고 한국기업 평가로부터 부여받은 회사채(1년 이상의 장기채권)의 신용등급 자료를 이용한다. 현재 나이스 신용평가는 회사채 신용등급을 총 22 개로 구분하고 있으나 한국신용평가와 한국기업평가는 20 개 등급으로 구분하고 있다.12) 따라서 기존 연구와 같이 기업별 회사채 신용등급에 수치를 부여하되(신용등급이 높을 경우 더 높은 수치 부여) 국내의 복수평가제도를 고려하여 여러 개의 신용등급 중에서 가장 보수적으로(낮은) 평가된 신용등급을 기준으로 하고자 한다.13)

다음으로 기업의 신용평점은 Kis-Value에서 제공하는 KIS 신용평점을 이용한다. KIS 신용평점은 부실예측모형과 재무평점모형을 결합하여 기업의 재무적 신용도를 구간별로 제시한 것이다. 여기서 신용평점은 총 10 개 등급(최우수 1 등급 최하위 10 등급)으로 구분되며, 최우수 1 등급에는 1 의 값이 부여되고 순차적으로 10 등급에는 가장 낮은 점수인 10 의 값을 부여하는

12 ) 회사채 신용등급에 있어 $\mathrm{AAA}$ 등급부터 $\mathrm{B}^{-}$등급(16개 등급)까지는 3 대 신용평가사 모두에서 동일하게 구분하나 $\mathrm{CCC}$ 등급 이하부터는 한국기업평가 및 한국신용평가는 4 개 등급 $(\mathrm{CCC}, \mathrm{CC}, \mathrm{C}, \mathrm{D})$ 으로 구분하고 나이스 신용평가는 6 개 등급 $(\mathrm{CCC}+, \mathrm{CCC}, \mathrm{CCC}-, \mathrm{CC}, \mathrm{C}, \mathrm{D})$ 으로 구분하여 적용하고 있다

13) 복수평가제도는 회사채를 발행하는 경우 최소 2 곳 이상의 신용평가기관으로부터 신용등급을 평가 받아야 하는 제도를 의미한다. 
The Effect of Managerial Share Pledges on the Cost of Debt

구조이다. 본 연구는 KIS 신용평점을 이용하되, 결과해석의 용이성을 위해 신용평점은 역순으로 (신용등급이 가장 좋은 1 등급 기업에는 10 의 신용평점을 부여) 이용하고자 한다.

\section{2 .2 대응표본 구성}

대주주의 주식담보대출 여부는 그들의 선택으로 내생적(endogenous)으로 결정된다. 따라서 내생성을 최대한 통제하기 위해 대응 표본 구성을 토대로 분석을 행하고자 한다. 여기서 대응 표본 구성은 성향점수매칭(propensity score matching: PSM)을 이용하고자 한다. 즉, 주식담보 대출이 없는 기업군(control sample) 중에서 주식담보대출이 존재하는 기업(treatment sample)과 가장 유사한 특성을 갖는 기업을 대응 표본으로 구성하여 타인자본비용과의 관련성을 상호·비교 하고자 한다.

$\mathrm{PSM}$ 을 이용하는 경우 어떠한 변수를 기준으로 대응 표본을 구성할 것인지가 중요한 고려 사항이 될 수 있다. 왜냐하면 분석표본과 대응 표본은 특정 연구에서 검정하고자 하는 내용을 제외하면 여타 다른 요인들은 비슷한 속성을 지녀야 하기 때문이다. 일례로 본 연구의 경우 주식담보대출 여부가 타인자본비용에 영향을 미치는지를 분석한다. 따라서 어떠한 특성을 갖는 기업의 경우 대주주가 주식담보대출을 행하는지를 파악한 후 해당 요인을 활용하여 대응 표본을 구성할 필요가 있다.

기존 연구에 의하면 기업 특성이나 소유구조 또는 성장성 등은 대주주의 주식담보대출에 영향을 미칠 수 있음을 제시하고 있다. 따라서 해당 요인을 고려하여 대응표본을 구성하고 있으나 세부적인 변수 선정에 있어서는 연구자별로 차이가 있다. Anderson and Puleo(2020)는 기업규모, 부채비율, 지배구조지수, 배당수익율, 장부가/시가 비율, $\mathrm{ROA}$, 이사회 규모, 기관투자자 및 대주주 지분율을 활용하여 대응 표본을 구성하며, $\mathrm{Xu}(2021)$ 는 기업규모, 부채비율, 매출액 성장률, 최대주주지분율, 경영자보상, 이사회지분, 회계감사기관(10대) 여부, 국영기업 여부, $\mathrm{KZ}$ 지수(재무적 제약) 등을 이용하고 있다. 반면, Ouyang et al.(2018)은 기업규모, ROA, 공기업 여부만을 대응표본 구성을 위한 변수로 활용하고 있다. 다음으로 국내시장의 경우 Cho and Yang(2019)은 최대주주 보통주 지분율, 기업규모, 과거 기간의 주식수익률 표준편차, 매출액 증가율, 부채비율, 영업이익률, 잉여현금흐름, 업력 및 애널리스트 보고서 수를 이용하고 있다. 반면, Noh(2019)는 기업규모, 부채비율, ROA, 업력을 이용하고 있다. 기존 연구에서 소유구조 측면, 기업 특성, 성장성 등의 측면을 고려하여 대응 표본을 구성하는 점을 고려하여 본 연구도 이를 고려하고자 한다.

보다 구체적인 대응 표본 구성 방법은 다음과 같다. 우선 소속 시장별(유가증권 또는 코스닥) 그리고 연도별로 기업들을 구분한 후 대주주의 주식담보대출 내역이 존재하는 기업은 1 의 값을, 그렇지 않은 기업은 0의 값을 부여한다. 이후 기업규모와 ROA, 부채비율, 시가/장부가 비율, 외국인 투자자 지분율을 활용한 로짓 회귀분석을 수행한 후 주식담보대출이 발생할 확률값 (propensity score)을 추정한다.14) 여기서 확률값(성향점수)은 대주주가 주식담보대출을 받는 기업군에 속할 조건부 확률로 정의할 수 있으며, 추정된 성향점수를 이용하여 가장 유사한

14) 추가적인 독립변수를 고려한 경우에도 전반적으로 결과는 유사하였다. 
한국증권학회지 제 50 권 6 호 (2021)

성향점수를 가진 대응 표본을 구성한다. 본 연구는 분석표본과 대응 표본의 성향점수 차이를 일정 수준으로 유지하기 위하여 캘리퍼(caliper) 방식을 이용하여 대응 표본을 구성한다(caliper= $1 \%$, with replacement). ${ }^{15)}$

\subsection{3 분석모형}

대주주의 주식담보대출과 타인자본비용의 관련성은 식 (4) 식 (6) 모형을 이용하여 분석하며, 주식담보대출에 따른 타인자본비용의 변화가 어떠한 요인에 기인하는지는 식 (7) 및 식 (8)의 모형을 이용하여 검증한다.

우선, 식 (4)는 대주주의 주식담보대출 여부가 타인자본비용에 영향을 미치는지를 분석하는 모형으로서, 종속변수인 $C O D$ 는 식 (1) 식 (3)을 이용한 회계 측면 타인자본비용 및 회사채 신용등급 그리고 신용평점을 의미한다. 해당 식에서 Pledge Dum 는 특정 연도에 대주주의 주식담보대출이 존재하는 기업(분석표본)은 1 의 값을 갖고, 그렇지 않은 기업(대응표본)은 0 의 값을 갖는다. 다음으로 식 (5)는 기업의 주식담보대출 수준(총 발행주식 대비 주식담보대출주식 비율)에 따라 타인자본비용에 어떠한 영향을 미치는지를 분석하는 모형이다. 식 (5)에서 Pledge Out 은 총 발행주식 대비 기업·연도별로 총계한 주식담보대출 비율을 의미한다. 그리고 식 (6)은 대주주 개인 측면의 주식담보대출 수준에 따른 타인자본비용의 영향을 분석하는 것이다. 종속변수는 식 (6)에서 Pledge Own은 대주주 개인별 보유한 주식 수 대비 주식담보대출의 비율을 기업별로 평균한 수치이다.

추가로 통제변수(Control Var.)는 기존 연구를 토대로 타인자본비용(회계 측면 또는 신용 등급)에 영향을 미친다고 알려진 변수를 이용한다. 이를 위해 전년도 말 총자산(Total Assets), 전년도 말의 영업이익을 총자산으로 나눈 영업이익률 $(R O A)$ 및 총부채를 총자산으로 나눈 부채비율 $(L E V)$, 전년도 말 자기자본의 시장가치(보통주 발행주식 수 $\times$ 주가)를 장부가치로 나눈 시가/장부가 비율 $(M B)$, 전년도 말 최대주주 및 특수관계인 지분율(Ownership) 및 외국인 투자자 지분율(Foreign)을 모형에 포함한다. 아울러 대규모기업집단 소속여부(Chaebol)와 시장구분 더미 변수 $(K O S P I)$ 도 모형에 포함하고자 한다. 또한, 연도와 산업효과를 통제하기 위해 연도더미와 산업더미(표준산업분류표 중분류 기준)도 모형에 포함하여 분석을 시행하고자 한다.

$$
\begin{aligned}
& C O D_{i, t}=\beta_{0}+\beta_{1} \text { Pledge Dum }{ }_{i, t}+\text { Control } \operatorname{Var}_{i, t}+\varepsilon_{i, t} \\
& C O D_{i, t}=\beta_{0}+\beta_{1} \text { Pledge Out } i, t+\text { Control } \operatorname{Var}_{i, t}+\varepsilon_{i, t} \\
& C O D_{i, t}=\beta_{0}+\beta_{1} \text { Pledge Own } n_{i, t}+\text { Control } \operatorname{Var}_{i, t}+\varepsilon_{i, t}
\end{aligned}
$$

한편, 대주주의 주식담보대출이 타인자본비용에 영향을 미친다면 이는 경영자의 위험추구를 억제하는 긍정적인 측면 또는 경영자가 과도한 위험을 추구하는 부정적인 측면에 기인할 수 있으며, 경영자의 사익추구 환경이 용이함에 따른 전반적인 기업가치 하락 측면에 의해 타인자본이 영향을 받았을 가능성도 있다. 따라서 이를 검증하기 위해 식 (7)과 식 (8)의 모형을 이용하여 분석하고자 한다.

15) 성향점수가 가장 유사한 기업을 대응 표본으로 하는 최근사(nearest neighbor) 방법도 있으나, 성향점수에 차이가 큰 경우에도 대응 표본으로 선정된다는 한계점이 있어 캘리퍼 방식을 이용하였다. 
The Effect of Managerial Share Pledges on the Cost of Debt

우선, 식 (7)에서 설명변수인 주식담보대출 관련 변수(Pledge)는 식 (4) 식 (6)과 동일하게 이용하고, 경영자의 위험추구와 관련된 대용변수는 기업의 투자나 자금조달활동과 관련된 변수를 고려하고자 한다. 이를 위해 전년 대비 당해연도의 부채비율 변화 $\triangle L E V)$, 연구개발비 변화 $(\triangle R D)$ 및 자본적지출 변화 $\triangle C A P E X)$ 를 이용하고자 한다.

$$
\begin{aligned}
& \triangle L E V_{i, t}=\beta_{0}+\beta_{1} \text { Pledge }_{i, t}+\text { Control } \operatorname{Var}_{i, t}+\varepsilon_{i, t} \\
\text { (or } \triangle R D_{i, t} \text { ) } & \text { (or } \triangle C A P E X_{i, t} \text { ) }
\end{aligned}
$$

마지막으로 식 (8)은 대주주의 주식담보대출에 따른 타인자본비용 변화가 그들의 사익추구에 기인하여 발생하는지를 검증하는 모형이다. 만약, 대주주의 주식담보대출로 인한 타인자본비용의 증가가 주로 지배주주의 사익추구 가능성이 높은 기업에서 발생한다면 그렇지 않은 기업과 차별적인 결과를 보일 것으로 기대해 볼 수 있다. 따라서 해당 가능성을 검증하기 위해 식 (8)의 모형을 이용한다.

식 (8)에서 종속변수는 식 (4)와 동일하게 회계 측면 그리고 신용등급 측면에서의 타인자본 비용이다. 그리고 주식담보대출 관련 변수(Pledge)는 식 (4) 식 (6)과 동일하게 이용하고, Agency는 대리인 문제의 대용변수로써 외국인투자자 지분율과 최대주주 및 특수관계인의 지분율 수준을 고려한 변수를 이용하고자 한다.16)

$$
C O D_{i, t}=\beta_{0}+\beta_{1} \text { Pledge }_{i, t}+\beta_{2} \text { Agency }_{i, t}+\beta_{3} \text { Pledge }_{i, t} \times \text { Agency }_{i, t}+\text { Control } \operatorname{Var}_{i, t}+\varepsilon_{i, t}
$$

\section{4. 분석 결과}

<표 1>은 본 연구에서 사용한 변수들에 대한 설명이다. 우선 Pledge Dum 는 특정 연도 말 기준 대주주 등의 주식담보대출내역이 존재하면 1 의 값을 갖고, 그렇지 않으면 0 의 값을 갖는 더미변수이다. Pledge Out은 특정 연도 말 기준 대주주 등이 받은 주식담보대출 수량을 합산한 후 해당 기업의 총 발행주식 수로 나눈 수치이고, Pledge Own은 대주주 등의 개인별 보유한 지분 대비 주식담보대출 비중을 평균한 수치이다. 타인자본비용과 관련된 변수인 DCOST1 $\sim D C O S T 3$ 은 식 (1) 식 (3)을 토대로 추정한 회계 측면의 타인자본비용이다.17) 그리고

16) 국내시장을 대상으로 한 외국인투자자의 영향에 대해 단기이익을 추구하거나 과다 배당을 요구한다는 견해가 있다. 하지만, 다수 연구에서 외부감시주체로서 경영자를 모니터링하여 대리인 문제가 완화되고 지배구조가 개선될 수 있다는 연구 결과가 제시되고 있다(Ahn et al., 2005; Park and Lee, 2006; Kim and Jung, 2011; Kim and Jang, 2014). 한편, 지배주주의 지분이 일정 수준 이상으로 증가하여 지배주주의 기업 통제력이 커지면 참호효과(entrenchment effect)가 나타날 수 있고 이로 인해 지배주주의 사익 추구 가능성은 더욱 커질 수 있다(Zingales, 1994; Chay and Moon, 2005; Ko et al., 2008).

17) DCOST 의 총 금융비용은 이자비용+사채이자+사채상환손실-사채상환이익+건설자금이자로 계산한 것이고, $D \operatorname{COST2}$ 의 세후이자비용은 이자비용 $\times(1$-법인세율 $)$ 로 계산한 것이다. 
$\ln (1+$ Kis Score) 는 KIS 신용평점에 자연로그를 취한 것이며, $\ln ($ Credit Score)는 회사채 신용등급에 수치를 부여하여 자연로그를 취한 수치를 의미한다.

\section{〈표 1〉변수설명}

본 연구에서 사용한 변수들의 설명이다.

\begin{tabular}{ll}
\hline \multicolumn{1}{c}{ 변수 } & \multicolumn{1}{c}{ 변수설명 } \\
\hline Pledge Dum & 대주주, 임원 등의 주식담보대출이 있으면 1, 아니면 0 \\
Pledge Out & 대주주, 임원 등의 주식담보대출 수량 합계 / 발행주식 수 \\
Pledge Own & 대주주, 임원 등의 개인별 보유주식 대비 주식담보대출 비중 \\
DCOST1 & 총금융비용 / 평균이자발생부채 \\
DCOST2 & 세후이자비용 / 장단기부채의 평균 \\
DCOST3 & (이자비용+사채이자) / 총부채에서 이연부채를 차감한 평균 \\
$\ln (1+$ Kis Score) & Kis-value에서 제공하는 신용평점의 자연로그 값 \\
$\ln ($ Credit Score) & 가장 보수적으로 평가된 회사채 신용등급의 자연로그 값 \\
$\ln ($ Total Assets) & 전년도 말 총자산의 자연로그 값 \\
ROA & 전년도 말 영업이익 / 총자산 \\
LEV & 전년도 말 부채총계 / 총자산 \\
MB & 전년도 말 (보통주 발행주식 수 × 주가) / 자기자본 장부가치 \\
RD & 전년도 말 연구개발비 / 총자산 \\
CAPEX & 전년도 말 자본적지출 / 총자산 \\
Ownership & 전년도 말 최대주주 및 특수관계인 지분율 \\
Foreign & 전년도 말 외국인투자자 지분율 \\
Chaebol & 대규모기업집단 소속기업은 1, 아니면 0 \\
KOSPI & 유가증권시장 소속기업은 1, 코스닥시장 소속기업은 0 \\
\hline
\end{tabular}

<표 2>는 본 연구 표본의 연도별 현황이다. 2009년부터 분석표본은 증가하고 있으며, 시장을 구분한 경우 코스닥 소속 기업이 더 큰 비중을 차지하고 있다. 그리고 대규모기업집단(Chaebol) 소속 기업은 더 낮은 비중을 차지하고 있다.18)

다음으로 <표 $3>$ 은 본 연구에서 사용한 변수들의 기초통계량 분석 결과를 정리한 것이다. <표 3>의 기초통계량에 대한 분석 결과를 보면, Pledge Out의 평균은 0.0599 , 그리고 최대값은 0.5055로 나타난다. 즉, 대주주의 주식담보대출이 가장 높은 수준을 보이는 기업에서는 총 발행주식 대비 약 $51 \%$ 의 주식이 담보대출을 위해 활용되고 있다. 추가로 Pledge Own의 경우 평균은 0.1800 으로 나타나고 있어 대주주 등은 그들이 보유한 총 지분 중에서 평균적으로 약 $18 \%$ 수준의 지분을 주식담보대출로 이용하고 있다.

18) 전술한 바와 같이 성향점수매칭을 위해 본 연구에서 사용한 방법은 캘리퍼 매칭이다. 여기서 캘리퍼 매칭은 매칭의 질을 증대시키기 위해 일정한 범위 이내에 해당되는 경우에만 짝을 이루어 분석에 포함하며, 그렇지 않으면 분석표본에서 제외한다. 본 연구기간 동안의 주식담보대출 총 기업 수는 기본적으로 연도별로 증가하는 추세를 보이나, <표 2>의 표본 현황에서는 2014년부터 급격하게 증가하고 있다. 이는 성향점수매칭 과정에서 대응 표본 매칭이 원활하게 이루어지지 않아 표본에서 제외된 사유에 기인한다. 
The Effect of Managerial Share Pledges on the Cost of Debt

〈표 2〉 표본 현황

본 연구 표본의 연도별 현황이다.

\begin{tabular}{|c|c|c|c|c|c|}
\hline & \multirow{2}{*}{ Total } & \multicolumn{2}{|c|}{ 시장구분 } & \multicolumn{2}{|c|}{ 대규모기업집단 구분 } \\
\hline & & KOSDAQ & KOSPI & non-Chaebol & Chaebol \\
\hline 2009 & 24 & 14 & 10 & 22 & 2 \\
\hline 2010 & 44 & 24 & 20 & 38 & 6 \\
\hline 2011 & 58 & 32 & 26 & 50 & 8 \\
\hline 2012 & 100 & 54 & 46 & 83 & 17 \\
\hline 2013 & 194 & 110 & 84 & 166 & 28 \\
\hline 2014 & 790 & 478 & 312 & 686 & 104 \\
\hline 2015 & 896 & 536 & 360 & 761 & 135 \\
\hline 2016 & 1,032 & 598 & 434 & 889 & 143 \\
\hline 2017 & 1,166 & 690 & 476 & 1,034 & 132 \\
\hline 2018 & 1,304 & 782 & 522 & 1,146 & 158 \\
\hline Total & 5,608 & 3,318 & 2,290 & 4,875 & 733 \\
\hline
\end{tabular}

〈표 3〉기초통계량

Pledge Dum 는 대주주 등의 주식담보대출 내역이 있는 기업은 1의 값을, 아니면 0의 값을 갖는다.Pledge Out 은 대주주 등의 총 주식담보대출 수량을 발행주식 수로 나눈 것이고, Pledge Own은 대주주 등의 개인별 보유주식 대비 주식담보대출 비중이다. DCOST1 DCOST3은 식 (1) 식 (3)을 이용한 회계 측면의 타인자본 비용이다. $\ln (1+$ Kis Score $)$ 는 KIS 신용평점에 자연로그를 취한 것이고, $\ln ($ Credit Score $)$ 는 회사채 신용등급에 수치를 부여하여 자연로그를 취한 것이다. $\ln ($ Total Assets)은 전년도 말 총자산에 자연로그를 취한 것이며, $R O A$ 는 전년도 말 영업이익을 총자산으로 나눈 것이고, $L E V$ 는 전년도 말 총부채를 총자산으로 나눈 값이다, $M B$ 는 (전년도 말 보통주 발행주식 수×주가)를 자기자본으로 나눈 값이다. $R D$ 는 전년도 말 연구개발비를 총자산으로 나눈 값이고, $C A P E X$ 는 전년도 말 자본적지출을 총자산으로 나눈 것이다. Ownership은 전년도 말 최대주주 및 특수관계인 지분율이고, Foreign은 전년도 말 외국인투자자 지분율이다. Chaebol은 대규모기업집단 소속기업은 1의 값을 아니면 0의 값을 가지며, $K O S P I$ 는 유가증권시장 소속기업은 1 의 값을 아니면 0의 값을 갖는다. 본 연구에서 이상치(outlier)가 분석 결과에 미치는 영향을 통제하기 위하여 모든 변수는 상, 하위 각각 $1 \%$ 를 기준으로 조정(winsorization) 하였다.

\begin{tabular}{|c|c|c|c|c|c|c|}
\hline & $\mathrm{N}$ & Mean & Median & Std & Min & $\operatorname{Max}$ \\
\hline Pledge Dum & 5,608 & 0.5000 & 0.5000 & 0.5000 & 0.0000 & 1.0000 \\
\hline Pledge Out & 5,608 & 0.0599 & 0.0000 & 0.0993 & 0.0000 & 0.5055 \\
\hline Pledge Own & 5,608 & 0.1800 & 0.0000 & 0.2728 & 0.0000 & 1.0000 \\
\hline DCOST1 & 5,608 & 0.0456 & 0.0360 & 0.0394 & 0.0000 & 0.3745 \\
\hline DCOST2 & 5,608 & 0.0416 & 0.0339 & 0.0357 & 0.0015 & 0.3470 \\
\hline DCOST3 & 5,608 & 0.0433 & 0.0348 & 0.0374 & 0.0025 & 0.3745 \\
\hline $\ln (1+$ Kis Score $)$ & 5,608 & 1.8657 & 1.9459 & 0.2710 & 1.3863 & 2.3026 \\
\hline $\ln ($ Credit Score $)$ & 967 & 3.0622 & 3.1355 & 0.2483 & 0.6931 & 3.3322 \\
\hline $\ln$ (Total Assets) & 5,608 & 19.1424 & 18.8731 & 1.3524 & 16.5502 & 23.5609 \\
\hline $\mathrm{ROA}$ & 5,608 & 0.0268 & 0.0267 & 0.0605 & -0.1109 & 0.2798 \\
\hline LEV & 5,608 & 0.4304 & 0.4331 & 0.1874 & 0.0718 & 0.8920 \\
\hline $\mathrm{MB}$ & 5,608 & 1.8531 & 1.2185 & 1.8862 & 0.3315 & 13.1757 \\
\hline $\mathrm{RD}$ & 5,608 & 0.0202 & 0.0080 & 0.0293 & 0.0000 & 0.1692 \\
\hline CAPEX & 5,608 & 0.2794 & 0.2626 & 0.1959 & 0.0058 & 0.8141 \\
\hline Ownership & 5,608 & 0.3804 & 0.3699 & 0.1625 & 0.1305 & 0.8144 \\
\hline Foreign & 5,608 & 0.0600 & 0.0216 & 0.0949 & 0.0000 & 0.7302 \\
\hline Chaebol & 5,608 & 0.1307 & 0.0000 & 0.3371 & 0.0000 & 1.0000 \\
\hline KOSPI & 5,608 & 0.4083 & 0.0000 & 0.4916 & 0.0000 & 1.0000 \\
\hline
\end{tabular}


한국증권학회지 제 50 권 6 호 (2021)

그리고 식 (1) 식 (3)을 이용한 회계 측면의 타인자본비용 (DCOST1 DCOST3) 평균은 각각 $0.0456,0.0416$ 그리고 0.0433 으로 나타난다. 따라서 평균 기준으로 볼 때 식 (1)의 총금융 비용을 고려하는 경우의 타인자본비용이 가장 높게 나타나고 있다. 그리고 신용평점 및 신용등급에 로그를 취한 Kis Score와 Credit Score의 평균은 각각 1.8657, 3.0622로 나타난다.19)

통제변수와 관련하여 $R O A$ 의 평균은 0.0268 로 나타나며, $L E V$ 의 평균은 0.4304 로 총자산 대비 부채 비중은 평균적으로 $43 \%$ 수준을 차지하고 있다. 그리고 $M B$ 의 평균은 1.8531 로 1 보다 높게 나타나고 있으며, 최대주주 및 특수관계인 지분율(Ownership) 평균은 0.3804이고 최대값은 0.8144 로 나타나 기업별로 편차가 존재한다. 또한, 외국인투자자 지분율(Foreign)의 평균은 0.0600 으로 나타난다. Chaebol 의 평균은 0.1307로 대규모기업집단 소속 기업이 약 $13 \%$ 가량 차지하고 있으며, KOSPI의 평균은 0.4083으로 코스닥시장에 소속된 기업 대비 유가증권시장 소속 기업의 비중이 더 낮게 분포하고 있다.

\section{1 경영자의 주식담보대출 여부에 따른 특성 비교}

본 절에서는 대주주 등의 주식담보대출 내역이 존재하는 기업(분석표본)과 그렇지 않은 기업(대응표본)의 회계 측면 및 신용등급 측면의 타인자본비용을 비교하고, 기업특성 등에 있어 두 표본 간 차이가 있는지를 일차적으로 분석한다.

$<$ 표 4>는 분석표본과 대응 표본의 타인자본비용 및 기업특성을 비교한 분석 결과이다. 분석 결과를 보면, 회계 측면의 타인자본비용 ( $D C O S T 1 \sim D C O S T 3)$ 과 신용등급 측면 타인자본비용 (Kis Score 와 Credit Score) 모두에서 두 표본 간 유의적인 차이를 보인다. 우선, 대주주의 주식담보 대출이 있는 표본(Pledge =1)은 DCOST1,DCOST2,DCOST3의 평균이 각각 $0.0478,0.0435$ 그리고 0.0452 로 나타나며 대응 표본 $(P l e d g e=0)$ 보다 유의적으로 큰 값을 보인다. 따라서 대주주 등이 주식담보대출을 받는 기업의 경우에는 그렇지 않은 기업보다 회계 측면으로 추정한 타인자본 비용이 더 크게 나타나고 있다.

이는 신용등급 측면을 이용한 경우에도 일관된 결과를 보인다. 대주주 등의 주식담보대출이 존재하는 표본에서는 Kis Score 값의 평균이 1.8453 그리고 Credit Score는 2.9934로 나타난다. 반면, 대응 표본의 경우에는 Kis Score와 Credit Score의 값의 평균이 각각 1.8862과 3.1287로 분석표본보다 더 크게 나타나며 유의적인 차이를 보인다. 따라서 대주주의 주식담보대출이 존재하는 기업의 경우에는 그렇지 않은 기업보다 신용평점이나 신용등급이 더 낮게 나타나고 있어, 신용등급 측면의 타인자본비용도 더 큼이 확인된다.

한편, 본 연구에서 대응 표본 구성을 위해 사용한 기업규모( Total Assets)와 ROA, 부채비율 ( $L E V)$, 시가/장부가 비율 $(M B)$, 외국인투자자 지분율(Foreign) 변수의 경우, Foreign 과 $M B$ 를 제외한 변수에서 대주주의 주식담보대출 표본과 대응 표본 간 유의적인 차이가 나타나지 않는다. 따라서 성향점수를 이용한 대응 표본 구성은 적절하게 이루어졌다고 판단해 볼 수 있다.

19) Credit Score는 회사채를 발행한 기업에서만 신용등급이 존재한다. 따라서 전체표본인 5,608건과 차이가 있다. 
The Effect of Managerial Share Pledges on the Cost of Debt

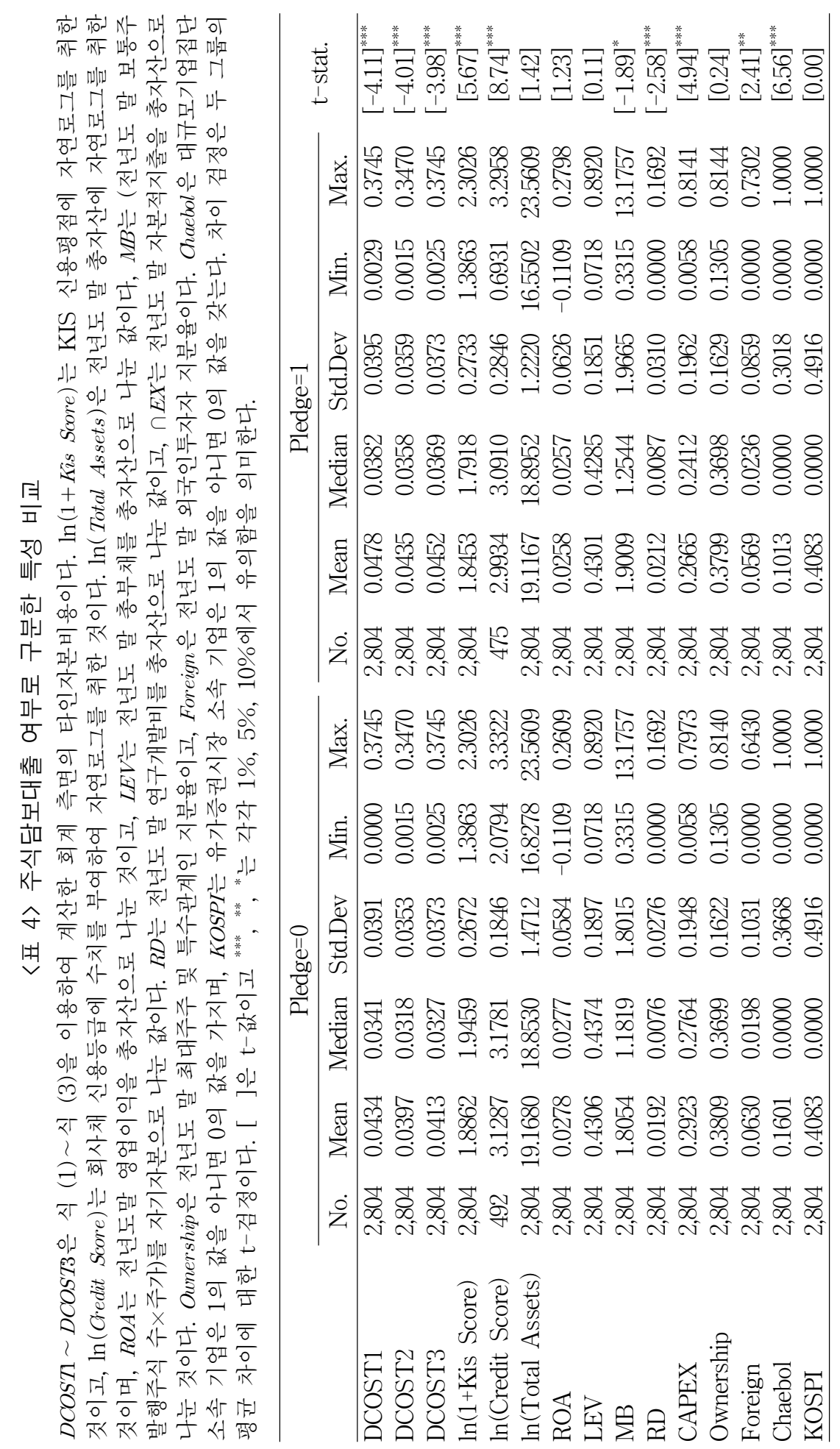


한국증권학회지 제50권 6호 (2021)

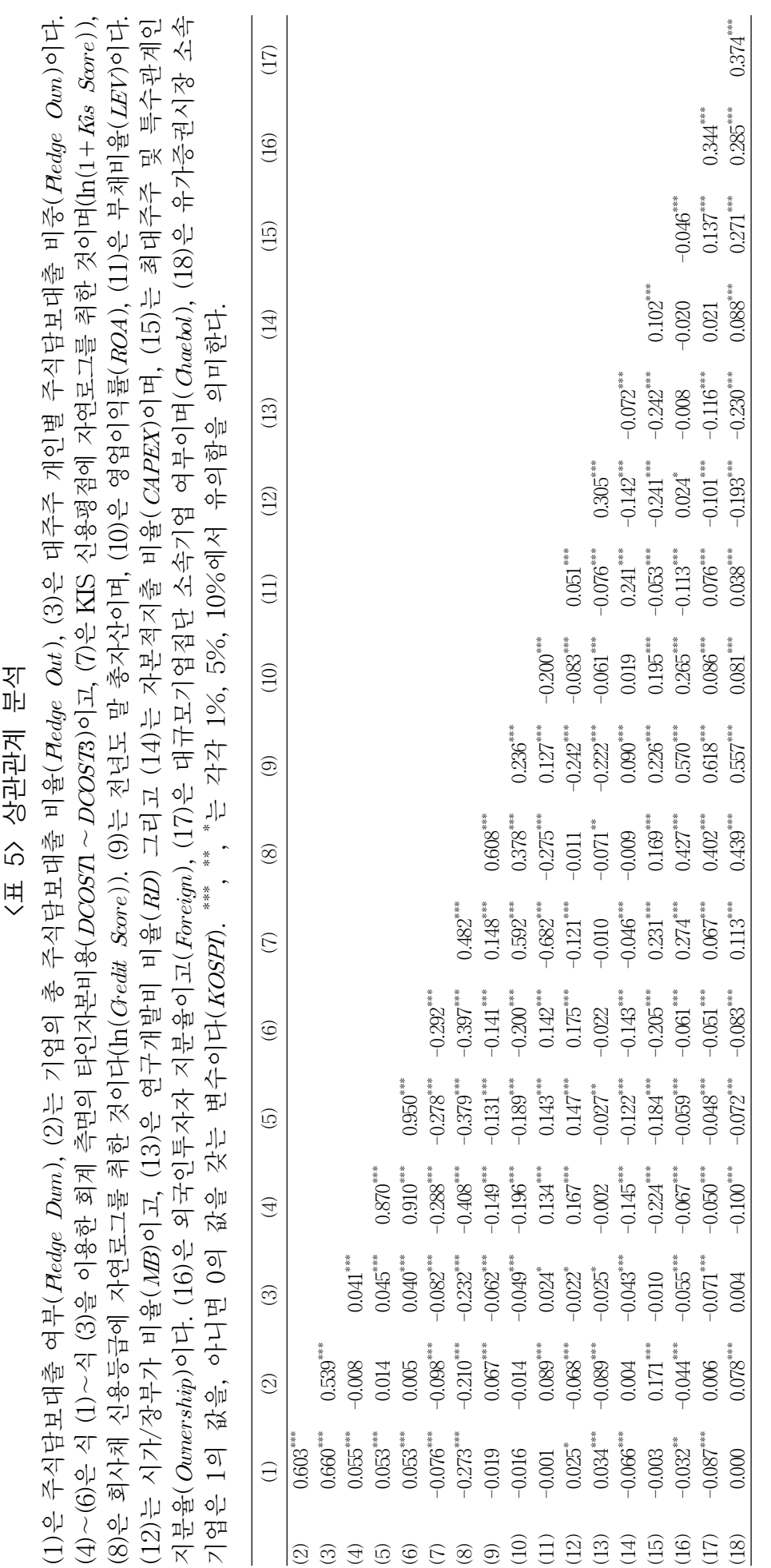


The Effect of Managerial Share Pledges on the Cost of Debt

다음으로 <표 $5>$ 는 회귀분석에 앞서 본 연구에서 사용한 변수들의 상관관계를 분석한 결과이다. 분석 결과를 보면 주식담보대출 관련 변수(Pledge Dum Pledge Own)와 회계 측면의 타인자본 비용 ( $(D C O S T 1 \sim D C O S T 3)$ 은 대체로 유의적인 양 $(+)$ 의 관련성을 보인다. 반면, 신용등급 측면의 타인자본비용(Kis Score, Credit Score)과는 유의적인 음(-)의 관련성을 보인다. 따라서 대주주의 주식담보대출과 타인자본비용 간에는 일련의 관련성이 있음을 추론해 볼 수 있다. 추가로 본 연구에서 사용한 통제변수 간에 다중공선성(multicollinearity) 문제를 우려할 만큼 높은 상관 관계는 나타나고 있지 않다.

\section{2 경영자의 주식담보대출이 타인자본비용에 미치는 영향}

본 절에서는 식 (4) 식 (6)의 분석모형을 이용하여 대주주 등의 주식담보대출과 타인자본비용 (회계 측면 또는 신용등급 측면)의 관련성이 기업특성이나 산업요인과 같은 여타변수를 통제한 상황에서도 설명 가능한지를 분석한다.

우선, <표 6>은 대주주 등의 주식담보대출이 사후적 성격을 갖는 회계 측면의 타인자본비용에 어떠한 영향을 미치는지를 분석한 결과이다. 모형 (1) 모형 (3)은 식 (1)의 총금융비용을 이용한 것이고(DCOST1), 모형 (4) 모형 (6)은 식 (2)의 세후이자비용을 이용한 것이며(DCOST2), 모형 (7) 모형 (9)는 식 (3)의 이자비용과 사채이자를 (DCOST3)을 이용하여 추정한 회계 측면의 타인자본비용을 종속변수로 활용한 것이다.

분석 결과를 보면, 우선 모형 (1)과 모형 (4) 그리고 모형 (7)의 Pledge Dum 계수는 각각 $0.0050,0.0040,0.0040$ 의 유의적인 양 $(+)$ 으로 나타난다. 따라서 대주주의 주식담보대출이 존재하는 기업(분석표본)의 경우에는 그렇지 않은 기업(대응표본)보다 회계 측면의 타인자본 비용이 더 높게 나타난다.

이는 대주주의 주식담보대출 수준을 고려한 경우에도 유사한 결과를 보인다. 모형 (2)와 모형 (5), 그리고 모형 (8)에서 Pledge Out 계수는 일관되게 유의적인 양(+)의 값을 보인다. 따라서 기업의 총 발행주식 대비 대주주 등의 담보대출 주식 수량이 증가할수록 타인자본비용은 증가하고 있다. 또한, 대주주 개인별 주식담보대출 수준을 고려한 모형 (3)과 모형 (6), 그리고 모형 (9)에서도 Pledge Own 계수 값은 유의적인 양(+)으로 나타난다. 따라서 대주주 개인 측면 에서도 그들이 보유한 주식 대비 담보대출의 비율이 높아질수록 타인자본비용은 증가한다.

다음으로 <표 7>은 대주주의 주식담보대출이 사전적 성격을 갖는 신용등급 측면의 타인자본 비용에 어떠한 영향을 미치는지를 분석한 결과이다. 모형 (1) 모형 (3)은 KIS 신용평점을 이용한 것이고(Kis Score), 모형 (4) 모형 (6)은 회사채 신용등급(CreditScore)을 이용한 분석 결과이다. 여기서 Kis Score 또는 CreditScore 의 경우 해당 수치가 높을수록 신용평점이 높거나 신용등급이 높음을 의미하므로, 주식담보대출이 존재하는 기업이 타인자본비용에 부정적인 영향을 미친다면, 신용등급 측면의 타인자본비용에 음(-)의 영향을 미칠 가능성이 있다.

분석 결과를 보면, 모형 (1)과 모형 (4)에서 Pledge Dum 계수는 -0.0300 과 -0.0590 의 유의적인 음(-)으로 나타난다. 따라서 대주주의 주식담보대출이 있는 기업의 경우에는 신용평점 또는 신용등급이 유의적으로 낮게 나타난다. 또한, 모형 (2)와 모형 (5)에서 Pledge Out 계수는 유의적인 
한국증권학회지 제 50 권 6호 (2021)




The Effect of Managerial Share Pledges on the Cost of Debt

음(-)의 값으로 나타나며, 모형 (3)과 모형 (6)에서도 Pledge Own 계수는 일관적으로 유의적인 음(-)의 값을 보이고 있다. 즉, 기업 수준에서 대주주 등의 주식담보대출 수준이 높거나 대주주 개인 수준에서 보유 주식 대비 주식담보대출의 비중이 높을수록 신용평점 또는 신용등급은 감소하고 있다. 따라서 신용등급을 이용한 경우에도 <표 $6>$ 의 회계 측면 타인자본비용을 이용한 분석과 일관된 결과가 나타나고 있다.

〈표 7〉 주식담보대출과 타인자본비용(신용등급) 회귀분석 결과

$\ln (1+$ Kis Score $)$ 는 KIS 신용평점에 자연로그를 취한 것이고, $\ln ($ Credit Score $)$ 는 회사채 신용등급에 수치를 부여하여 자연로그를 취한 것이다. Pledge Dum은 주식담보대출 기업은 1 , 아니면 0 의 값을 갖는다. Pledge Out 은 대주주 등의 총 주식담보대출 수량을 발행주식 수로 나눈 것이고, Pledge Oun 은 대주주 등의 개인별 주식담보대출 비중이다. 여타 통제변수는 <표 1> 변수설명과 같다. [ ]은 회귀계수의 기업별 군집표준오차(clustered standard error)이고 ${ }^{* * *},{ }^{* *},{ }^{*}$ 는 각각 $1 \%, 5 \%, 10 \%$ 에서 유의함을 의미한다.

\begin{tabular}{|c|c|c|c|c|c|c|}
\hline & \multicolumn{3}{|c|}{$\ln (1+$ Kis Score $)$} & \multicolumn{3}{|c|}{$\ln ($ Credit Score $)$} \\
\hline & (1) & (2) & (3) & (4) & (5) & (6) \\
\hline Intercept & $\begin{array}{l}11.9230^{* * *} \\
{[2.554]}\end{array}$ & $\begin{array}{l}10.6920^{* * *} \\
{[2.475]}\end{array}$ & $\begin{array}{l}11.3760^{* * *} \\
{[2.408]}\end{array}$ & $\begin{array}{l}17.1380^{* * *} \\
{[5.022]}\end{array}$ & $\begin{array}{c}16.8620^{* * * *} \\
{[4.891]}\end{array}$ & $\begin{array}{l}14.9090^{* * *} \\
{[5.467]}\end{array}$ \\
\hline Pledge Dum & $\begin{array}{c}-0.0300^{* * *} \\
{[0.006]}\end{array}$ & & & $\begin{array}{c}-0.0590^{* * *} \\
{[0.017]}\end{array}$ & & \\
\hline Pledge Out & & $\begin{array}{l}-0.1540^{* * *} \\
{[0.032]}\end{array}$ & & & $\begin{array}{c}-0.1710^{* *} \\
{[0.078]}\end{array}$ & \\
\hline Pledge Own & & & $\begin{array}{c}-0.0360^{* * * *} \\
{[0.010]}\end{array}$ & & & $\begin{array}{c}-0.0810^{*} \\
{[0.044]}\end{array}$ \\
\hline $\ln$ (Total Assets) & $\begin{array}{l}0.0080^{* *} \\
{[0.004]}\end{array}$ & $\begin{array}{l}0.0080^{* *} \\
{[0.004]}\end{array}$ & $\begin{array}{c}0.0070^{*} \\
{[0.004]}\end{array}$ & $\begin{array}{l}0.0690^{* * *} \\
{[0.010]}\end{array}$ & $\begin{array}{l}0.0710^{* * *} \\
{[0.010]}\end{array}$ & $\begin{array}{l}0.0690^{* * *} \\
{[0.009]}\end{array}$ \\
\hline $\mathrm{ROA}$ & $\begin{array}{l}1.8640^{* * *} \\
{[0.050]}\end{array}$ & $\begin{array}{l}1.8560^{* * *} \\
{[0.050]}\end{array}$ & $\begin{array}{l}1.8610^{* * *} \\
{[0.050]}\end{array}$ & $\begin{array}{l}0.7670^{* * *} \\
{[0.182]}\end{array}$ & $\begin{array}{l}0.7860^{* * *} \\
{[0.187]}\end{array}$ & $\begin{array}{l}0.7870^{* * *} \\
{[0.185]}\end{array}$ \\
\hline LEV & $\begin{array}{c}-0.87700^{* * *} \\
{[0.019]}\end{array}$ & $\begin{array}{c}-0.8710^{* * *} \\
{[0.019]}\end{array}$ & $\begin{array}{c}-0.8770^{* * * *} \\
{[0.019]}\end{array}$ & $\begin{array}{c}-0.3010^{* * *} \\
{[0.077]}\end{array}$ & $\begin{array}{c}-0.2770^{* * *} \\
{[0.077]}\end{array}$ & $\begin{array}{c}-0.2810^{* * * *} \\
{[0.078]}\end{array}$ \\
\hline $\mathrm{MB}$ & $\begin{array}{r}-0.0020 \\
{[0.002]}\end{array}$ & $\begin{array}{r}-0.0030 \\
{[0.002]}\end{array}$ & $\begin{array}{r}-0.0020 \\
{[0.002]}\end{array}$ & $\begin{array}{r}0.0060 \\
{[0.005]}\end{array}$ & $\begin{array}{r}0.0070 \\
{[0.006]}\end{array}$ & $\begin{array}{r}0.0070 \\
{[0.006]}\end{array}$ \\
\hline Ownership & $\begin{array}{l}0.1300^{* * *} \\
{[0.021]}\end{array}$ & $\begin{array}{l}0.1450^{* * *} \\
{[0.021]}\end{array}$ & $\begin{array}{l}0.1300^{* * * *} \\
{[0.021]}\end{array}$ & $\begin{array}{l}0.1980^{* *} \\
{[0.085]}\end{array}$ & $\begin{array}{c}0.2050^{* *} \\
{[0.084]}\end{array}$ & $\begin{array}{l}0.1980^{* *} \\
{[0.089]}\end{array}$ \\
\hline Foreign & $\begin{array}{l}0.1920^{* * *} \\
{[0.043]}\end{array}$ & $\begin{array}{l}0.1880^{* * *} \\
{[0.043]}\end{array}$ & $\begin{array}{l}0.1950^{* * *} \\
{[0.043]}\end{array}$ & $\begin{array}{r}0.0370 \\
{[0.067]}\end{array}$ & $\begin{array}{r}0.0410 \\
{[0.066]}\end{array}$ & $\begin{array}{r}0.0560 \\
{[0.067]}\end{array}$ \\
\hline Chaebol & $\begin{array}{r}-0.0020 \\
{[0.012]}\end{array}$ & $\begin{array}{r}0.0010 \\
{[0.012]}\end{array}$ & $\begin{array}{r}0.0030 \\
{[0.012]}\end{array}$ & $\begin{array}{r}0.0210 \\
{[0.026]}\end{array}$ & $\begin{array}{r}0.0290 \\
{[0.027]}\end{array}$ & $\begin{array}{r}0.0290 \\
{[0.027]}\end{array}$ \\
\hline KOSPI & $\begin{array}{c}0.0150^{*} \\
{[0.008]}\end{array}$ & $\begin{array}{l}0.0160^{* *} \\
{[0.008]}\end{array}$ & $\begin{array}{l}0.0160^{* *} \\
{[0.008]}\end{array}$ & $\begin{array}{c}0.0890^{*} \\
{[0.048]}\end{array}$ & $\begin{array}{c}0.0910^{*} \\
{[0.048]}\end{array}$ & $\begin{array}{c}0.0900^{*} \\
{[0.049]}\end{array}$ \\
\hline Year and industry fixed effect & Yes & Yes & Yes & Yes & Yes & Yes \\
\hline No. of observations & 5,608 & 5,608 & 5,608 & 967 & 967 & 967 \\
\hline $\mathrm{F}$-value & $199.03^{* * *}$ & $199.04^{* * *}$ & $197.41^{* * *}$ & $20.20^{* * * *}$ & $19.75^{* * *}$ & $19.81^{* * *}$ \\
\hline Adj. R-squared & 0.7311 & 0.7312 & 0.7295 & 0.5439 & 0.5381 & 0.5388 \\
\hline
\end{tabular}


한국증권학회지 제 50 권 6 호 (2021)

전체적으로 대주주의 주식담보대출이 존재하는 기업은 타인자본비용(회계 또는 신용등급 측면)이 높게 나타나며, 대주주 등의 주식담보대출 비중이 증가할수록 타인자본비용은 높아지고 있다. 전술한 바와 같이 Ouyang et al.(2018)은 중국 시장의 경우 주식담보대출이 채권발행비용을 증가시켜 타인자본비용에 부정적인 영향을 미친다고 제시하고 있다. 반면, 미국 시장을 대상으로 한 연구에서는 주식담보대출을 받은 기업은 채권수익률 스프레드가 감소하여 타인자본비용에 긍정적인 영향을 미친다는 상반된 결과를 제시하고 있다(Puelo et al., 2020).

국내시장을 대상으로 한 본 연구의 결과는 Ouyang et al.(2018)의 연구를 지지하고 있다. 따라서 자본시장이 선진화된 미국 시장과는 차별적으로 중국이나 우리나라와 같은 신흥시장의 경우에는 대주주의 주식담보대출이 채권자에게 부정적인 영향을 미칠 수 있어 타인자본비용이 증가하는 것으로 추론해 볼 수 있다.

한편, 주식담보대출이 타인자본비용에 미치는 부정적인 영향은 경영자의 과도한 위험추구 행위에 따른 채권자와의 이해상충에 기인하여 발생할 수 있다(Puelo et al., 2020).20) 또한, 대주주의 주식담보대출이 그들의 사적이익을 추구하기 위한 목적으로 행해지는 경우에는 지배주주-소액주주 간 대리인 문제가 심화될 수 있으며, 기업가치가 하락하고 주식수익률이 급락하는 등 전반적인 기업위험이 증대될 수 있다(Anderson and Puleo, 2020; Chen et al., 2007; Lim and Park, 2019). 즉, 지배주주의 사익추구 환경이 용이한 기업의 경우에는 대주주의 주식담보대출로 기업가치가 하락할 수 있으며, 이로 인해 채권자에게 부정적인 영향을 미칠 수 있다. 이상과 같이 대주주의 주식담보대출로 인한 타인자본비용의 증가는 다양한 사유에 기인할 수 있으므로 이를 규명해 볼 필요가 있다.

\section{3 주식담보대출과 타인자본비용: 위험추구 측면}

본 절에서는 식 (7)의 분석모형을 이용하여 주식담보대출에 따른 타인자본비용(회계 또는 신용등급 측면)의 증가가 경영자의 과도한 위험추구 측면에 기인하는지를 분석한다.

<표 8>은 대주주 등이 주식담보대출을 받은 경우에 기업 차원의 재무레버리지를 증가시키는 등 과도한 위험추구를 행하는지 여부를 검증한 것이다. 모형 (1) 모형 (3)은 전년 대비 당해연도의 부채비율 변화 $(\triangle L E V)$ 를 이용한 것이고, 모형 (4) 모형 (6)은 전년 대비 당해연도의 연구개발비 변화 $(\triangle R D)$ 를 종속변수로 이용한 것이다. 그리고 모형 (7) 모형 (9)는 전년 대비 당해연도의 자본적지출 변화 $\triangle \triangle A P E X)$ 를 이용한 분석 결과이다.

분석 결과를 보면, 모형 (1)과 모형 (7)에서 Pledge Dum 계수는 각각 -0.0080, -0.0040의 유의적인 음(-)으로 나타나며, 유의성은 낮긴 하나 모형 (4)에서도 일관되게Pledge Dum 계수는 음(-)으로 나타난다. 따라서 대주주 등이 주식담보대출을 받은 기업의 경우에는 대응 표본보다 전년 대비 총부채 수준과 연구개발투자, 그리고 자본적지출이 유의적으로 감소하고 있다.

20) 반대로 대주주는 주가하락 시 야기될 수 있는 마진콜 위험을 방어하기 위한 목적으로 과도하게 위험을 추구하기보다는 안전한 투자안을 통해 위험을 회피하는 의사결정을 행할 수 있다. 하지만, 위험을 회피하는 경우에는 채권자와의 대리인 문제가 완화될 수 있어 타인자본비용이 감소할 수 있다(Puelo et al., 2020). 
The Effect of Managerial Share Pledges on the Cost of Debt

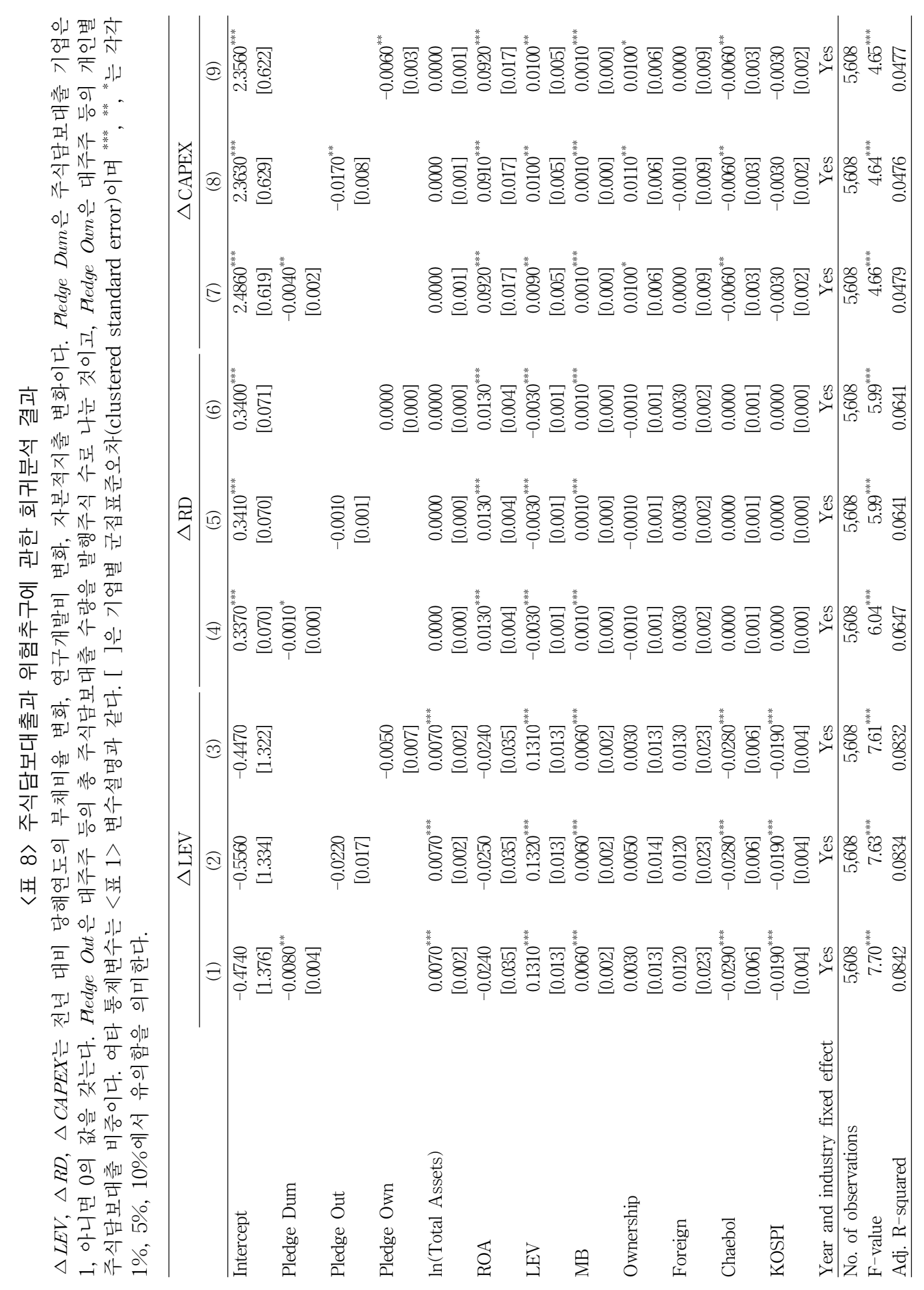


한국증권학회지 제50권 6호 (2021)

또한, 모형 (8)에서 Pledge Out 계수는 -0.0170의 유의적인 음(-)의 값으로 나타나 총 발행주식 대비 대주주의 주식담보대출 비중이 증가할수록 자본적지출이 유의적으로 감소하고 있다. 그리고 모형 (9)의 대주주 개인 수준 주식담보대출을 고려한 경우에도 Pledge Own 계수가 -0.0060의 유의적인 음(-)의 값을 보여 대주주 개인의 주식담보대출 비율이 증가할수록 자본적지출은 감소하고 있다.

만약, 주식담보대출에 따른 타인자본비용의 증가가 지배주주의 과도한 위험추구에 따른 전반적인 기업 위험에 기인한다면, 주식담보대출을 받은 기업에서는 재무레버리지(부채비율)가 증대되거나 연구개발비 또는 자본적지출이 증가할 것으로 기대해 볼 수 있다. 반면, 본 연구의 결과에 의하면 대주주의 주식담보대출이 존재하는 기업은 대응 표본보다 재무레버리지 또는 연구개발비 지출 등이 감소하고 있어 오히려 과소투자 행태를 보이며 보다 위험 회피적인 성향으로 나타난다. 따라서 대주주 등의 주식담보대출로 인한 기업의 타인자본비용 증가는 경영자의 과도한 위험추구 행위에 기인한 결과로 판단하기에는 한계가 있다.21)

\section{4 주식담보대출과 타인자본비용: 사익추구 측면}

본 절에서는 식 (8)의 분석모형을 이용하여 주식담보대출에 따른 타인자본비용의 증가가 주로 지배주주의 사익추구 환경이 용이한 기업에서 발생하는지를 검증한다. 대주주의 사익추구가 용이한 기업은 주식담보대출이 발생하는 경우 지배주주와 소액주주 간 대리인 문제가 심화될 수 있으며, 기업가치의 하락 및 전반적인 기업위험이 증대될 수 있어 채권자는 더 높은 프리미엄을 요구할 가능성이 있다. 따라서 주식담보대출이 존재하는 기업 중에서도 지배주주의 사익추구 가능성이 높은 기업에서는 타인자본비용이 더 높을 개연성이 있다.

<표 9>는 주식담보대출을 받은 기업 중에서도 대주주의 사익추구 가능성이 높은 기업에서 타인자본비용에 차별적인 영향을 미치는지에 대해 회계 측면의 타인자본비용 대용변수를 이용하여 검증한 것이다. 기존 연구에 의하면 대체로 외국인투자자의 지분율과 지배구조와는 양 $(+)$ 의 상관관계가 존재한다는 결과가 제시되고 있다. 따라서 외국인투자자의 지분율이 높을수록 기업을 모니터링함으로써 대주주의 사익추구 행위를 억제할 가능성이 있다. 또한, 대주주의 지분이 높아 영향력을 크게 행사할 수 있는 기업의 경우에는 사익추구 또한 쉬우므로 소액주주나 채권자에게 부정적인 영향을 미칠 수 있다.22)

21) 추가로 대주주의 사익추구 여부가 타인자본비용을 증가시키는지 여부를 검증하는 식 (8)의 모형과 동일하게 타인자본비용을 종속변수로 두고 분석을 수행하였다. 구체적으로 우선, 전년 대비 당해 연도의 부채비율 변화 $\triangle L E V)$ 와 연구개발비 변화 $\triangle R D)$ 그리고 자본적지출 변화 $\triangle C A P E X)$ 를 설명변수로 활용하였다. 또한, 당해연도의 부채비율 $(L E V)$ 과 연구개발비 $(R D)$ 그리고 자본적지출 $(C A P E X)$ 을 설명변수로 이용하였다. 분석결과에 의하면 대주주의 주식담보대출과 위험추구 관련 변수(부채비율 변화 등)의 교차항(interaction term) 계수는 전체적으로 유의적인 결과가 나타나지 않고 있다. 따라서 타인자본비용의 증가가 경영자의 과도한 위험추구에 기인하는지 않는 것으로 판단된다.

22) 지배구조의 대용변수로 활용되는 외국인투자자 또는 최대주주 지분수준 이외에도 외부기업지배구조 메커니즘으로서 상품시장에서의 경쟁 정도도 활용될 수 있다. 상품시장에서의 경쟁이 치열할수록 
The Effect of Managerial Share Pledges on the Cost of Debt

<표 9>에서 Panel A는 식 (1)의 총금융비용(DCOST1)을 종속변수로 이용한 것이고, Panel $\mathrm{B}$ 는 식 (2)의 세후이자비용(DCOST2), 그리고 Panel C는 식 (3)의 이자비용과 사채이자 (DCOST3)를 고려한 타인자본비용을 종속변수로 이용한 것이다. 그리고 모형 (1) 모형 (3)은 대주주의 주식담보대출 여부(Pledge Dum), 모형 (4) 모형 (6)은 총 발행주식 대비 대주주의 주식담보대출 비중(Pledge Out), 모형 (7) 모형 (9)는 대주주의 개인 수준 주식담보대출 비중 (Pledge Own)을 주요 설명변수로 활용한 것이다. 또한, High(Foreign)과 High(Ownership)은 연도별 외국인지분율 및 최대주주 등의 지분율을 기준으로 상, 중, 하 3개 그룹으로 분류한 후 해당 값들이 가장 높은 그룹은 1 의 값을, 아니면 0 의 값을 부여한 것이다.

우선 Panel A의 분석 결과를 보면, 모형 (2)와 모형 (4), 그리고 모형 (6)에서 High (Ownership) 계수는 유의적인 음(-)의 값으로 나타난다. 따라서 최대주주 등의 지분이 높은 기업에서는 타인자본비용이 낮게 나타난다.23) 반면, 교차항의 계수 값을 보면, 모형 (2)에서 Pledge Dum $\times \operatorname{High}$ (Ownership) 는 0.0070으로 유의적인 양(+)으로 나타난다. 또한, 모형 (4)와 모형 (6)에서도 Pledge Out $\times$ High(Ownership) 및 Pledge Own $\times \operatorname{High}$ (Ownership) 회귀계수는 0.0270과 0.0070 으로 나타나 일관적으로 유의적인 양 $(+)$ 의 값을 보인다. 즉, 최대주주 및 특수관계인 지분이 높은 기업의 경우에는 대주주의 주식담보대출 내역이 존재하거나 기업 수준 또는 대주주 개인 수준의 주식담보대출 비중이 높아질수록 타인자본비용의 감소 폭은 줄어드는 것으로 해석해 볼 수 있다.24)

이는 Panel B와 Panel C의 분석에서도 일관된 결과를 보인다. 우선 Panel B의 결과에서 $\operatorname{High}$ (Ownership) 계수는 유의적인 음(-)의 값으로 나타나나, 모형 (2)의 Pledge Dum $\times$ High (Ownership) 와 모형 (4)의 Pledge Out $\times$ High(Ownership) 회귀계수는 각각 0.0060과 0.0280의 유의적인 양(+)의 값으로 나타난다. 다음으로, Panel C의 분석 결과에서도 High(Ownership) 계수는 동일하게 유의적인 음(-)의 값을 보이고 있으며, 모형 (2)의 Pledge Dum $\times$ High (Ownership)와

경영자를 규율하는 수단으로 작용하여 기업지배구조에 영향을 미칠 수 있기 때문이다. 따라서 허핀달-허쉬만 지수(Herfindahl-Hirschman Index)를 이용하여 산업 내 경쟁 정도를 추정한 후 추가적인 분석을 수행하였다. 전체적인 분석결과에 의하면, 상품시장에서의 경쟁이 치열한 기업의 경우에는 대주주의 주식담보대출에도 불구하고 타인자본비용이 감소하고 있음이 확인되었다. 즉, 지배구조가 취약하여 대주주의 사익추구 가능성이 높은 기업의 경우에는 대주주가 주식담보대출을 행하면 타인자본비용이 증가한다고 판단할 수 있다.

23) 대주주 지분이 타인자본비용에 미치는 영향에 있어 소유경영체제인 경우에는 대주주의 안정적인 경영활동이 채권자 이해와 부합하여 타인자본비용에 긍정적인 영향(감소)을 미칠 수 있으나, 소유권 집중에 따른 대주주의 사익추구가 기업가치를 하락시킴으로써 담보가치를 축소하고 이에 따라 타인자본비용에 부정적인 영향(상승)을 미칠 가능성도 있다(Kim and Kim, 2012). Kim and $\operatorname{Kim}(2012)$ 에 의하면, 국내시장의 경우 대주주의 지분이 증가할수록 타인자본비용이 감소하나, 타인자본의존도가 높거나 성장성이 낮은 기업에서는 대주주 지분이 타인자본비용에 미치는 영향이 약화된다는 결과를 제시하고 있다.

24) 일례로 모형 (2)에서 High (Ounership) 의 계수는 -0.0410이며, Pledge Dum $\times$ High (Ounership) 의 계수는 0.0070 이다. 따라서 대주주의 주식담보대출 내역이 존재하는 기업의 경우에는 타인자본비용이 $-0.0370(-0.0440+$ 0.0070) 만큼만 감소한다. 
한국증권학회지 제50권 6호 (2021)

모형 (4)의 Pledge Out $\times$ High(Ownership), 그리고 모형 (6)의 Pledge Own $\times$ High(Ownership) 회귀계수 모두에서 일관적으로 유의적인 양 $(+)$ 의 값으로 나타나고 있다. 따라서 대주주의 주식담보대출이 존재하는 기업의 경우에는 타인자본비용의 감소폭을 축소시키고 있다.

\section{〈표 9> 주식담보대출과 사익추구에 관한 회귀분석 결과: 회계 측면}

Panel A Panel C는 각각 식 (1) 식 (3)의 회계 측면 타인자본비용을 종속변수로 이용한 것이다. Pledge Dum 은 주식담보대출 기업은 1, 아니면 0의 값을 갖는다. Pledge Out 은 대주주 등의 총 주식담보대출 수량을 발행주식 수로 나눈 것이고, Pledge Own 은 대주주 등의 개인별 주식담보대출 비중이다. High(Foreign) 과 High (Ownership) 은 외국인지분율과 최대주주 등의 지분율을 기준으로 3개 그룹으로 분류한 후 해당 수치가 가장 높은 그룹은 1 의 값을, 아니면 0 의 값을 부여한 것이다. 여타 통제변수(other control variables)는 전년도 말 총자산(Total Assets), 전년도 말의 영업이익률 $(R O A)$ 및 부채비율 $(L E V)$, 전년도 말 시가/장부가 비율 $(M B)$, 대규모기업집단 소속여부 (Chaebol)와 유가증권시장 소속여부(KOSPI), 연도더미 및 산업더미 이다. [ ]은 기업별 군집표준오차(clustered standard error)이며 ***, ** *는 각각 $1 \%, 5 \%, 10 \%$ 에서 유의함을 의미한다.

Panel A: DCOST1

\begin{tabular}{|c|c|c|c|c|c|c|}
\hline & (1) & (2) & (3) & (4) & (5) & (6) \\
\hline \multirow[t]{2}{*}{ Intercept } & 1.0850 & 1.3820 & 0.9490 & 1.2260 & 1.1270 & 1.4650 \\
\hline & {$[0.900]$} & {$[0.932]$} & [0.928] & {$[0.951]$} & {$[0.916]$} & {$[0.926]$} \\
\hline \multirow[t]{2}{*}{ Pledge Dum } & $0.0050^{* * *}$ & 0.0030 & & & & \\
\hline & {$[0.002]$} & {$[0.002]$} & & & & \\
\hline \multirow[t]{2}{*}{ Pledge Out } & & & 0.0090 & -0.0030 & & \\
\hline & & & {$[0.007]$} & {$[0.008]$} & & \\
\hline \multirow[t]{2}{*}{ Pledge Own } & & & & & $0.0060^{* *}$ & 0.0030 \\
\hline & & & & & {$[0.003]$} & {$[0.003]$} \\
\hline \multirow[t]{2}{*}{ High(Foreign) } & 0.0010 & & 0.0000 & & -0.0020 & \\
\hline & {$[0.010]$} & & {$[0.009]$} & & [0.009] & \\
\hline \multirow[t]{2}{*}{ High(Ownership) } & & $-0.0440^{* * *}$ & & $-0.0400^{* * *}$ & & $-0.0380^{* * *}$ \\
\hline & & {$[0.006]$} & & {$[0.005]$} & & {$[0.005]$} \\
\hline \multirow[t]{2}{*}{ Pledge Dum $\times$ High(Foreign) } & -0.0020 & & & & & \\
\hline & {$[0.002]$} & & & & & \\
\hline \multirow[t]{2}{*}{ Pledge Dum $\times$ High(Ownership) } & & $0.0070^{* * * *}$ & & & & \\
\hline & & {$[0.002]$} & & & & \\
\hline \multirow[t]{2}{*}{ Pledge Out×High(Foreign) } & & & -0.0120 & & & \\
\hline & & & {$[0.010]$} & & & \\
\hline \multirow[t]{2}{*}{ Pledge Out×High(Ownership) } & & & & $0.0270^{* * *}$ & & \\
\hline & & & & {$[0.010]$} & & \\
\hline \multirow[t]{2}{*}{ Pledge Own $\times$ High(Foreign) } & & & & & -0.0010 & \\
\hline & & & & & {$[0.004]$} & \\
\hline \multirow[t]{2}{*}{ Pledge Own×High(Ownership) } & & & & & & $0.0070^{*}$ \\
\hline & & & & & & {$[0.004]$} \\
\hline Other control variables & Yes & Yes & Yes & Yes & Yes & Yes \\
\hline Year and industry fixed effect & Yes & Yes & Yes & Yes & Yes & Yes \\
\hline No. of observations & 5,608 & 5,608 & 5,608 & 5,608 & 5,608 & 5,608 \\
\hline $\mathrm{F}$-value & $14.92^{* * * *}$ & $16.46^{* * *}$ & $14.59^{* * *}$ & $16.09^{* * *}$ & $14.69^{* * *}$ & $16.07^{* * *}$ \\
\hline Adj. R-squared & 0.1623 & 0.1770 & 0.1590 & 0.1735 & 0.1600 & 0.1733 \\
\hline
\end{tabular}


The Effect of Managerial Share Pledges on the Cost of Debt

〈표 9〉 주식담보대출과 사익추구에 관한 회귀분석 결과: 회계 측면(계속)

Panel B: DCOST2

\begin{tabular}{|c|c|c|c|c|c|c|}
\hline & (1) & (2) & (3) & (4) & (5) & (6) \\
\hline Intercept & $\begin{array}{c}1.2310 \\
{[0.931]}\end{array}$ & $\begin{array}{c}1.3760 \\
{[0.956]}\end{array}$ & $\begin{array}{c}1.1880 \\
{[0.952]}\end{array}$ & $\begin{array}{c}1.2780 \\
{[0.978]}\end{array}$ & $\begin{array}{c}1.2830 \\
{[0.940]}\end{array}$ & $\begin{array}{c}1.4690 \\
{[0.948]}\end{array}$ \\
\hline Pledge Dum & $\begin{array}{l}0.0050^{* * *} \\
{[0.001]}\end{array}$ & $\begin{array}{r}0.0020 \\
{[0.002]}\end{array}$ & & & & \\
\hline Pledge Out & & & $\begin{array}{l}0.0150^{* *} \\
{[0.007]}\end{array}$ & $\begin{array}{r}0.0020 \\
{[0.007]}\end{array}$ & & \\
\hline Pledge Own & & & & & $\begin{array}{c}0.0060^{* *} \\
{[0.002]}\end{array}$ & $\begin{array}{r}0.0030 \\
{[0.003]}\end{array}$ \\
\hline High(Foreign) & $\begin{array}{r}0.0040 \\
{[0.009]}\end{array}$ & & $\begin{array}{r}0.0050 \\
{[0.009]}\end{array}$ & & $\begin{array}{r}0.0020 \\
{[0.009]}\end{array}$ & \\
\hline High(Ownership) & & $\begin{array}{c}-0.0320^{* * *} \\
{[0.005]}\end{array}$ & & $\begin{array}{c}-0.0310^{* * *} \\
{[0.005]}\end{array}$ & & $\begin{array}{c}-0.0280^{* * *} \\
{[0.005]}\end{array}$ \\
\hline Pledge Dum×High(Foreign) & $\begin{array}{r}-0.0010 \\
{[0.002]}\end{array}$ & & & & & \\
\hline Pledge Dum×High(Ownership) & & $\begin{array}{l}0.0060^{* * * *} \\
{[0.002]}\end{array}$ & & & & \\
\hline Pledge Out $\times$ High(Foreign) & & & $\begin{array}{r}-0.0140 \\
{[0.010]}\end{array}$ & & & \\
\hline Pledge Out×High(Ownership) & & & & $\begin{array}{c}0.0280^{* *} \\
{[0.011]}\end{array}$ & & \\
\hline Pledge Own $\times$ High(Foreign) & & & & & $\begin{array}{r}-0.0010 \\
{[0.004]}\end{array}$ & \\
\hline Pledge Own $\times$ High (Ownership) & & & & & & $\begin{array}{r}0.0060 \\
{[0.004]}\end{array}$ \\
\hline Other control variables & Yes & Yes & Yes & Yes & Yes & Yes \\
\hline Year and industry fixed effect & Yes & Yes & Yes & Yes & Yes & Yes \\
\hline No. of observations & 5,608 & 5,608 & 5,608 & 5,608 & 5,608 & 5,608 \\
\hline $\mathrm{F}$-value & $14.82^{* * *}$ & $15.88^{* * *}$ & $14.60^{* * *}$ & $15.67^{* * *}$ & $14.64^{* * *}$ & $15.55^{* * *}$ \\
\hline Adj. R-squared & 0.1613 & 0.1715 & 0.1591 & 0.1695 & 0.1595 & 0.1683 \\
\hline \multicolumn{7}{|l|}{ Panel C: DCOST3 } \\
\hline & (1) & (2) & (3) & (4) & (5) & (6) \\
\hline Intercept & $\begin{array}{r}1.1930 \\
{[0.913]}\end{array}$ & $\begin{array}{r}1.3920 \\
{[0.943]}\end{array}$ & $\begin{array}{r}1.1060 \\
{[0.936]}\end{array}$ & $\begin{array}{r}1.2650 \\
{[0.961]}\end{array}$ & $\begin{array}{r}1.2050 \\
{[0.926]}\end{array}$ & $\begin{array}{r}1.4510 \\
{[0.938]}\end{array}$ \\
\hline Pledge Dum & $\begin{array}{l}0.0050^{* * *} \\
{[0.002]}\end{array}$ & $\begin{array}{r}0.0020 \\
{[0.002]}\end{array}$ & & & & \\
\hline Pledge Out & & & $\begin{array}{c}0.0140^{*} \\
{[0.007]}\end{array}$ & $\begin{array}{r}-0.0010 \\
{[0.007]}\end{array}$ & & \\
\hline Pledge Own & & & & & $\begin{array}{c}0.0060^{* *} \\
{[0.003]}\end{array}$ & $\begin{array}{r}0.0020 \\
{[0.003]}\end{array}$ \\
\hline High(Foreign) & $\begin{array}{r}0.0030 \\
{[0.009]}\end{array}$ & & $\begin{array}{r}0.0030 \\
{[0.009]}\end{array}$ & & $\begin{array}{r}0.0010 \\
{[0.009]}\end{array}$ & \\
\hline High(Ownership) & & $\begin{array}{c}-0.0380^{* * *} \\
{[0.005]}\end{array}$ & & $\begin{array}{c}-0.0350^{* * *} \\
{[0.005]}\end{array}$ & & $\begin{array}{c}-0.0330^{* * *} \\
{[0.005]}\end{array}$ \\
\hline
\end{tabular}


한국증권학회지 제50권 6호 (2021)

〈표 9〉 주식담보대출과 사익추구에 관한 회귀분석 결과: 회계 측면(계속)

\begin{tabular}{|c|c|c|c|c|c|c|}
\hline & (1) & (2) & (3) & (4) & (5) & (6) \\
\hline Pledge Dum $\times$ High(Foreign) & $\begin{array}{r}-0.0020 \\
{[0.002]}\end{array}$ & & & & & \\
\hline Pledge Dum×High(Ownership) & & $\begin{array}{l}0.0070^{* * *} \\
{[0.002]}\end{array}$ & & & & \\
\hline Pledge Out×High(Foreign) & & & $\begin{array}{r}-0.0160 \\
{[0.010]}\end{array}$ & & & \\
\hline Pledge Out $\times$ High(Ownership) & & & & $\begin{array}{l}0.0300^{* * *} \\
{[0.012]}\end{array}$ & & \\
\hline Pledge Own $\times$ High(Foreign) & & & & & $\begin{array}{r}-0.0020 \\
{[0.004]}\end{array}$ & \\
\hline Pledge Own×High(Ownership) & & & & & & $\begin{array}{c}0.0090^{* *} \\
{[0.004]}\end{array}$ \\
\hline Other control variables & Yes & Yes & Yes & Yes & Yes & Yes \\
\hline Year and industry fixed effect & Yes & Yes & Yes & Yes & Yes & Yes \\
\hline No. of observations & 5,608 & 5,608 & 5,608 & 5,608 & 5,608 & 5,608 \\
\hline $\mathrm{F}$-value & $15.21^{* * *}$ & $16.54^{* * *}$ & $14.96^{* * *}$ & $16.25^{* * *}$ & $15.00^{* * *}$ & $16.18^{* * *}$ \\
\hline Adj. R-squared & 0.1651 & 0.1777 & 0.1626 & 0.1750 & 0.1630 & 0.1743 \\
\hline
\end{tabular}

이상의 결과를 종합해 볼 때, 대주주의 소유지분이 높아 그들의 사적이익 추구 환경이 보다 용이한 등 대리인 문제가 발생할 가능성이 높은 기업의 경우에는 대주주의 주식담보대출 여부에 따라 타인자본비용이 보다 높게 나타나며, 대주주의 주식담보대출 수준이 높아질수록 타인자본 비용이 증가(타인자본비용의 감소 폭이 약화)하고 있음을 추론해 볼 수 있다.

마지막으로 <표 $10>$ 은 신용평점과 신용등급과 같은 사전적 타인자본비용의 대용치를 이용하여 대주주의 사익추구 가능성이 높은 기업에서 타인자본비용이 차별적인지를 검증한 것이다. <표 $10>$ 에서 Panel A는 KIS 신용평점(Kis Score)을 종속변수로 이용한 것이고, Panel B는 회사채 신용등급(Credit Score)을 종속변수로 이용한 것이다. 그 외에 대주주의 주식담보대출 관련 변수나 대주주의 사익추구 가능성을 고려하는 변수는 <표 $9>$ 와 동일하게 이용하였다.

우선 Panel A의 KIS 신용평점을 이용한 분석 결과를 보면, 모형 (1)에서 High(Foreign) 계수 값은 0.1240 의 양(+)으로 나타난다. 따라서 외국인투자자 지분이 높은 기업의 경우에는 $\mathrm{KIS}$ 신용평점이 높게 나타난다. 한편, 주식담보대출과 외국인투자자 지분과의 교차항에 대한 분석 결과에서 Pledge Dum $\times$ High(Foreign) 계수 값은 0.0230의 유의적인 양(+)의 값으로 나타난다. 또한, 모형 (5)에서도 Pledge Dum $\times \operatorname{High(Foreign)~ㄱㅖㅅㅜㄴㅡㄴ~0.0470ㅇㅢ~ㅇㅠㅇㅢㅈㅓㄱㅇㅣㄴ~ㅇㅑㅇ(+)ㅇㅢ~}$ 값을 보인다. 따라서 외국인투자자 지분이 높은 기업의 경우에는 대주주가 주식담보대출을 받거나 대주주 개인 수준에서의 주식담보대출 비중이 증가할수록 KIS 신용평점은 더욱 높아지고 있다. 즉, 최대주주 및 특수관계인의 지분 수준이 높은 기업에서는 대주주의 주식담보대출 비중이 높아질수록 KIS 신용평점은 더욱 증가하고 있음을 알 수 있다. 
The Effect of Managerial Share Pledges on the Cost of Debt

한편, Panel B의 신용등급을 이용한 분석 결과를 보면, 모형 (2)와 모형 (4) 그리고 모형 (6)에서 High(Ownership) 계수는 유의적인 양(+)으로 나타나 최대주주 등의 지분이 증가할수록 신용등급은 상승하고 있다. 반면, 주식담보대출과 최대주주 지분과의 교호작용 분석에 있어서는

〈표 10〉 주식담보대출과 사익추구에 관한 회귀분석 결과: 신용등급 측면

Panel A는 KIS 신용평점, Panel B는 회사채 신용등급을 종속변수로 이용한 것이다. Pledge Dum은 주식 담보대출 기업은 1 , 아니면 0의 값을 갖는다. Pledge Out 은 대주주 등의 총 주식담보대출 수량을 발행주식 수로 나눈 것이고 Pledge Own 은 대주주 등의 개인별 주식담보대출 비중이다. High(Foreign) 과 High (Ownership)은 외국인지분율과 최대주주 등의 지분율을 기준으로 3 개 그룹으로 분류한 후 해당 수치가 가장 높은 그룹은 1 의 값을, 아니면 0 의 값을 부여한 것이다. 여타 통제변수(other control variables)는 전년도 말 총자산 (Total Assets), 전년도 말의 영업이익률 $(R O A)$ 및 부채비율 $(L E V)$, 전년도 말 시가/장부가 비율 $(M B)$, 대규모기업집단 소속여부(Chaebol)와 유가증권시장 소속여부(KOSPI), 연도더미 및 산업더미이다. [ ]은 기업별 군집표준오차(clustered standard error)이며 ${ }^{* * *},{ }^{* *}$, *는 각각 $1 \%, 5 \%, 10 \%$ 에서 유의함을 의미 한다.

Panel A: $\ln (1+$ Kis Score $)$

\begin{tabular}{|c|c|c|c|c|c|c|}
\hline & (1) & (2) & (3) & (4) & (5) & (6) \\
\hline Intercept & $\begin{array}{l}12.1370^{* * *} \\
{[2.266]}\end{array}$ & $\begin{array}{l}7.8140^{* * * *} \\
{[2.382]}\end{array}$ & $\begin{array}{l}11.7860^{* * * *} \\
{[2.246]}\end{array}$ & $\begin{array}{l}7.1120^{* * *} \\
{[2.297]}\end{array}$ & $\begin{array}{l}12.7760^{* * *} \\
{[2.269]}\end{array}$ & $\begin{array}{l}7.2050^{* * * *} \\
{[2.198]}\end{array}$ \\
\hline Pledge Dum & $\begin{array}{c}-0.0380^{* * * *} \\
{[0.007]}\end{array}$ & $\begin{array}{l}-0.0270^{* * * *} \\
{[0.007]}\end{array}$ & & & & \\
\hline Pledge Out & & & $\begin{array}{c}-0.1520^{* * * *} \\
{[0.034]}\end{array}$ & $\begin{array}{c}-0.1230^{* * *} \\
{[0.047]}\end{array}$ & & \\
\hline Pledge Own & & & & & $\begin{array}{c}-0.0500^{* * *} \\
{[0.011]}\end{array}$ & $\begin{array}{c}-0.0320^{* * *} \\
{[0.013]}\end{array}$ \\
\hline High(Foreign) & $\begin{array}{l}0.1240^{* * *} \\
{[0.047]}\end{array}$ & & $\begin{array}{l}0.1420^{* * * *} \\
{[0.045]}\end{array}$ & & $\begin{array}{l}0.1380^{* * *} \\
{[0.046]}\end{array}$ & \\
\hline High(Ownership) & & $\begin{array}{l}0.1460^{* * *} \\
{[0.027]}\end{array}$ & & $\begin{array}{l}0.1540^{* * *} \\
{[0.024]}\end{array}$ & & $\begin{array}{l}0.1360^{* * * *} \\
{[0.024]}\end{array}$ \\
\hline Pledge Dum $\times$ High(Foreign) & $\begin{array}{c}0.0230^{* *} \\
{[0.009]}\end{array}$ & & & & & \\
\hline Pledge Dum $\times$ High(Ownership) & & $\begin{array}{r}-0.0130 \\
{[0.011]}\end{array}$ & & & & \\
\hline Pledge Out $\times$ High(Foreign) & & & $\begin{array}{r}0.0620 \\
{[0.062]}\end{array}$ & & & \\
\hline Pledge Out×High(Ownership) & & & & $\begin{array}{r}-0.0580 \\
{[0.056]}\end{array}$ & & \\
\hline Pledge Own $\times$ High(Foreign) & & & & & $\begin{array}{c}0.0470^{* *} \\
{[0.020]}\end{array}$ & \\
\hline Pledge Own $\times$ High(Ownership) & & & & & & $\begin{array}{r}-0.0120 \\
{[0.020]}\end{array}$ \\
\hline Other control variables & Yes & Yes & Yes & Yes & Yes & Yes \\
\hline Year and industry fixed effect & Yes & Yes & Yes & Yes & Yes & Yes \\
\hline No. of observations & 5,608 & 5,608 & 5,608 & 5,608 & 5,608 & 5,608 \\
\hline $\mathrm{F}^{-}$-value & $193.67^{* * *}$ & $197.39^{* * *}$ & $192.60^{* * * *}$ & $197.19^{* * *}$ & $192.08^{* * *}$ & $195.55^{* * *}$ \\
\hline Adj. R-squared & 0.7283 & 0.7320 & 0.7272 & 0.7318 & 0.7266 & 0.7302 \\
\hline
\end{tabular}

\section{4}


한국증권학회지 제50권 6호 (2021)

〈표 10〉 주식담보대출과 사익추구에 관한 회귀분석 결과: 신용등급 측면(계속)

Panel B: $\ln ($ Credit Score)

\begin{tabular}{|c|c|c|c|c|c|c|}
\hline & (1) & (2) & (3) & (4) & (5) & (6) \\
\hline Intercept & $\begin{array}{c}15.9560^{* * *} \\
{[4.632]}\end{array}$ & $\begin{array}{c}16.6800^{* * * *} \\
{[6.066]}\end{array}$ & $\begin{array}{c}17.1380^{* * *} \\
{[4.459]}\end{array}$ & $\begin{array}{c}18.1360^{* * *} \\
{[6.544]}\end{array}$ & $\begin{array}{c}17.0690^{* * *} \\
{[4.840]}\end{array}$ & $\begin{array}{c}11.1020^{*} \\
{[5.889]}\end{array}$ \\
\hline Pledge Dum & $\begin{array}{l}-0.0740^{* * *} \\
{[0.022]}\end{array}$ & $\begin{array}{l}-0.0550^{* * *} \\
{[0.016]}\end{array}$ & & & & \\
\hline Pledge Out & & & $\begin{array}{c}-0.1610^{*} \\
{[0.093]}\end{array}$ & $\begin{array}{r}-0.0950 \\
{[0.089]}\end{array}$ & & \\
\hline Pledge Own & & & & & $\begin{array}{c}-0.1210^{*} \\
{[0.067]}\end{array}$ & $\begin{array}{c}-0.1270^{* *} \\
{[0.054]}\end{array}$ \\
\hline High(Foreign) & $\begin{array}{r}-0.0530 \\
{[0.066]}\end{array}$ & & $\begin{array}{r}-0.0300 \\
{[0.063]}\end{array}$ & & $\begin{array}{r}-0.0370 \\
{[0.061]}\end{array}$ & \\
\hline High(Ownership) & & $\begin{array}{l}0.2270^{\text {**** }} \\
{[0.074]}\end{array}$ & & $\begin{array}{l}0.2330^{* * *} \\
{[0.070]}\end{array}$ & & $\begin{array}{c}0.1530^{*} \\
{[0.090]}\end{array}$ \\
\hline Pledge Dum $\times$ High(Foreign) & $\begin{array}{r}0.0300 \\
{[0.026]}\end{array}$ & & & & & \\
\hline Pledge Dum×High(Ownership) & & $\begin{array}{r}-0.0220 \\
{[0.040]}\end{array}$ & & & & \\
\hline Pledge Out $\times$ High(Foreign) & & & $\begin{array}{r}0.0750 \\
{[0.107]}\end{array}$ & & & \\
\hline Pledge Out×High(Ownership) & & & & $\begin{array}{r}-0.2510 \\
{[0.269]}\end{array}$ & & \\
\hline Pledge Own $\times$ High(Foreign) & & & & & $\begin{array}{r}0.1070 \\
{[0.069]}\end{array}$ & \\
\hline Pledge Own×High(Ownership) & & & & & & $\begin{array}{c}0.1460^{* *} \\
{[0.059]}\end{array}$ \\
\hline Other control variables & Yes & Yes & Yes & Yes & Yes & Yes \\
\hline Year and industry fixed effect & Yes & Yes & Yes & Yes & Yes & Yes \\
\hline No. of observations & 967 & 967 & 967 & 967 & 967 & 967 \\
\hline $\mathrm{F}$-value & $19.46^{* * *}$ & $19.96^{* * *}$ & $18.89^{* * *}$ & $19.61^{* * *}$ & $19.20^{* * *}$ & $19.81^{* * *}$ \\
\hline Adj. R-squared & 0.5383 & 0.5449 & 0.5305 & 0.5403 & 0.5347 & 0.5429 \\
\hline
\end{tabular}

모형 (6)에서 Pledge Out $\times$ High(Ownership) 계수 값만 유의적일 뿐이며 다른 분석에서는 유의미한 결과가 나타나지 않고 있다.25)

전체적으로 <표 9>의 회계 측면 타인자본비용을 이용한 분석 결과와 <표 $10>$ 의 신용등급 측면을 이용한 분석 결과를 종합적으로 고려해 볼 때, 대체로 외국인투자자의 지분이 높아 경영자의 사익추구 활동을 견제할 수 있는 기업에서는 대주주가 주식담보대출 받더라도 타인자본 비용이 낮게 나타난다. 반면, 최대주주 등의 지분이 높은 기업 등 경영자의 사익추구 환경이

25) 앞에서 설명한 바와 같이 채권을 발행한 기업에서만 회사채 신용등급이 존재하므로 총 분석대상 표본과 표본 수에서 큰 차이가 있다. 따라서 Panel A의 외국인투자자 지분수준이나 최대주주 등의 지분 수준에 따른 결과와 비교할 때 $\mathrm{Panel} \mathrm{B}$ 의 유의미하지 않은 분석 결과는 극히 제한적인 표본만을 대상으로 분석이 이루어진 것에 기인한 결과일 수 있다. 
The Effect of Managerial Share Pledges on the Cost of Debt

보다 용이한 경우에는 대주주가 주식담보대출을 받으면 타인자본비용이 증가하고 있다. 즉, 국내시장의 경우 대주주의 주식담보대출로 인한 타인자본비용의 증가는 대주주의 사익추구 환경이 용이한 기업에서 명확한 결과를 보인다. 따라서 지배주주와 소액주주 간 대리인 문제로 인해 기업가치가 하락하고 전반적인 기업 위험이 증대될 수 있는 기업에서는 대주주가 주식담보대출을 받으면 채권자에게도 부정적인 영향을 미칠 수 있고, 이로 인해 타인자본비용이 증가할 수 있음을 실증적으로 확인할 수 있다.

\section{5. 결론}

본 연구는 기업 대주주나 주요주주 등의 주식담보대출 내역을 이용하여 주주의 개인적인 목적으로 행해지는 차입의사결정이 채권자와의 이해상충을 야기하는지를 분석하였다. 이를 위해 대주주의 주식담보대출 여부에 따라 분석표본과 대응 표본을 구성하였고, 주식담보대출이 존재하는 기업(분석표본)과 그렇지 않은 기업(대응 표본)의 회계 또는 신용등급 측면의 타인자본 비용이 차별적인지를 검증하였다. 또한, 주식담보대출에 따른 타인자본비용의 변화가 경영자의 과도한 위험추구나 사익추구 측면 중에서 주로 어떠한 요인으로 설명 가능한지를 규명하였다.

본 연구의 주요 분석 결과를 요약하면 다음과 같다. 첫째, 대주주의 주식담보대출이 존재하는 기업은 대응 표본보다 회계 또는 신용등급 측면 모두에서 타인자본비용이 유의적으로 높게 나타났다. 또한, 기업의 총 발행주식 대비 대주주의 주식담보대출 수준이 높거나 대주주의 개인별 보유 주식 대비 주식담보대출 비중이 높을수록 타인자본비용은 증가하였다. 둘째, 대주주가 주식담보대출을 받은 기업은 대응표본보다 재무레버리지(부채비율) 또는 연구개발비 지출이 감소하고 있다. 따라서 주식담보대출로 인한 타인자본비용의 증가는 경영자의 과도한 위험추구에 기인하지는 않고 있다. 셋째, 외국인투자자의 지분 수준이 높아 외부 감시인으로서 경영자의 사익추구 활동을 견제할 수 있는 기업은 타인자본비용이 낮게 나타났다. 반면, 최대주주의 지분 수준이 높은 등 경영자의 사익추구 환경이 보다 용이한 기업에서는 대주주가 주식담보대출을 행하면 타인자본비용이 증가하고 있음이 확인되었다.

전체적으로 대주주의 개인적 목적에 기인한 주식담보대출은 기업의 타인자본비용에 부정적인 영향을 미치고 있어 미국 시장을 대상으로 한 연구와는 차별적인 결과를 보였다. 그리고 해당 분석 결과는 경영자의 과도한 위험추구 행위보다는 지배주주의 사익추구 측면과 관련성이 높게 나타나 대주주의 주식담보대출은 소액주주 이외에도 채권자와 대리인 문제를 야기할 수 있음을 시사하고 있다.

최근 국외에서 대주주의 주식담보대출에 관하여 다양한 연구가 진행 중인 가운데 본 연구는 학술적 또는 실무적으로 다음과 같은 중요한 시사점을 전달해 줄 수 있을 것으로 기대된다. 우선 본 연구는 대주주의 주식담보대출이 기존 주주 측면 이외에 채권자에게도 영향을 미칠 수 있음을 실증적으로 규명하고 있다. 특히, 국내시장의 경우에도 대주주 개인의 주식담보대출이 채권자와 대리인 문제를 야기할 수 있는지 여부를 직접적으로 검증한다는 측면에서 이론적으로 중요한 의의가 있다.

\section{6}


한국증권학회지 제50권 6호 (2021)

한편, 본 연구의 결과는 대주주의 주식담보대출이 기존 주주 이외에도 채권자에게도 영향을 미칠 수 있어 관련 규정을 정비할 필요성이 있음을 시사한다. 우리나라는 2009년 자본시장 통합법이 도입되며 대주주의 주식담보대출을 공시하도록 의무화하고 있다. 여기서 최대주주 변경을 수반하는 주식담보대출은 별도로 공시하나(코스닥시장만 해당됨), 대주주나 특수관계인 등은 “주식등의대량보유상황보고서 제 2 부의 보유주식 등에 관한 계약”에서 주식담보대출 여부나 대출의 변경내역 등을 파악할 수 있다. 그런데 해당 공시내용의 경우 주식담보대출 수량이나 계약 일자 등은 확인 가능하나 대출목적은 파악할 수 없다. 재무적 제약 등에 직면한 기업에서는 대주주의 주식담보대출이 회사의 유동성 개선을 위한 목적으로 이루어질 수 있으며, 이는 해당 기업의 가치에 긍정적인 영향을 미칠 개연성도 공존한다. 따라서 대주주의 주식담보대출 목적을 소액주주나 채권자 등 이해관계자가 확인할 수 있도록 상세한 공시체계를 갖출 필요가 있다.

추가로 대주주의 주식담보대출에 따른 사익추구를 방지하기 위해 중국의 경우에는 2018년부터 상장회사의 주식담보대출 비율을 $50 \%$ 미만으로 제한하고 있으며, 대출 약정 기간은 3 년을 초과할 수 없도록 제한하고 있다. 그리고 대만의 경우 주식의 담보인정비율을 최대 $60 \%$ 로 제한하거나, 과도한 주식담보대출을 규제하기 위해 소유한 지분의 $50 \%$ 를 초과하는 주식에 대해서는 의결권을 제한하고 있다. 즉, 자본시장의 효율성 및 투명성 측면에서 본 연구 결과는 대주주 등의 주식담보대출 관련 규정을 더욱 견고하게 정비할 필요성이 있음을 시사한다. 
The Effect of Managerial Share Pledges on the Cost of Debt

\section{References}

Aboody, D., and B. Lev, 2000, Information Asymmetry, R\&D, and Insider Gains, Journal of Finance, Vol. 55 (6), pp. 2747-2766.

Ahn, Y. Y., H. H. Shin, and J. H. Chang, 2005, The Relationship between the Foreign Investor and Information Asymmetry, Korean Accounting Review, Vol. 30 (4), pp. 109-131.

Anderson, R., and M. Puleo, 2020, Insider Share-Pledging and Equity Risk, Journal of Financial Services Research, Vol. 58 (1), pp. 1-25.

Chan, K., H. K. Chen, S. Y. Hu, and Y. J. Liu, 2018, Share Pledges and Margin Call Pressure, Journal of Corporate Finance, Vol. 52, pp. 96-117.

Chay, J. B., and P. S. Moon, 2005, Discount Pricing of Preferred Stocks to Common Stocks: The Role of Liquidity premiums, Asian Review of Financial Research, Vol. 18 (2), pp. 263-287.

Chen, A., L. Kao, and Y. Chen, 2007, Agency Costs of Controlling Shareholders' Share Collateral with Taiwan Evidence, Review of Pacific Basin Financial Markets and Policies, Vol. 10 (2), pp. 173-191.

Chen, A., and L. Kao, 2011, Effect of Collateral Characteristics on Bank Performance: Evidence from Collateralized Stocks in Taiwan, Journal of Banking \& Finance, Vol. 35 (2), pp. 300-309.

Cho, E., and D. R. Yang, 2019, The Effect of Share Pledges on Payout Policy, Korean Journal of Financial Management, Vol. 36 (1), pp. 119-150.

DeJong, D., K. Liao, and D. XIe, Controlling Shareholder's Share Pledging and Accounting Manipulations, Working Paper, 2020, https://papers.ssrn.com/sol3/papers.cfm?abstract_ id $=3274388$.

Dou, Y., R. W. Masulis, and J. Zein, 2019, Shareholder Wealth Consequences of Insider Pledging of Company Stock as Collateral for Personal Loans, Review of Financial Studies, Vol. 32 (12), pp. 4810-4854.

Fernandes, N., and M. A. Ferreira, 2009, Insider Trading Laws and Stock Price Informativeness, Review of Financial Studies, Vol. 22 (5), pp. 1845-1887.

Francis, J. R, I. K. Khurana., and R. Pereira 2005, Disclosure Incentives and Effects on Cost of Capital around the World, Accounting Review, Vol. 80 (4), pp. 1125-1162.

Kao, L., J. Chiou, and A. Chen, 2004, The Agency Problems, Firm Performance and Monitoring Mechanisms: The Evidence from Collateralized Shares in Taiwan, Corporate Governance: An International Review, Vol. 12 (3), pp. 389-402.

Kim, M. A., and Y. J. Kim, 2012, Impact of Blockholder Ownership on the Cost of Debt: 
한국증권학회지 제 50 권 6호 (2021)

How does the Conflict between Blockholders and Creditors Change the Relation?, Korean Journal of Financial Management, Vol. 29 (2), pp. 1-28.

Kim, S., and Y. Jang, 2014, Investment Horizons of Foreign Investors and Corporate Investment-Cash Flow Sensitivities, Korean Journal of Financial Studies, Vol. 43 (5), pp. 785-810.

Kim, Y. H., and S. C. Jung, 2011, A Study on the Effects of Domestic and Foreign Outside Blockholders on Firm's Investment Policy, Asian Review of Financial Research, Vol. 24 (3), pp. 789-817.

Ko, H. J., Y. S. Park, K. Wee, and J. H. Lee, 2008, A Study on the Existence of the Voting Right Capture Strategy, Asian Review of Financial Research, Vol. 21 (2), pp. 1-27.

Ko, Y. W., and S. C. Lee, 2012, Information Asymmetry and Cost of Debt Capital, Korean International Accounting Review, Vol. 43, pp. 41-64.

Lee, A. Y., S. B. Chun, and S. S. Park, 2008, The Effect of Unfaithful Disclosure on the Cost of Debt, Korean Accounting Review, Vol. 33 (1), pp. 127-158.

Li, M., C. Liu, and T. Scott, 2019, Share Pledges and Firm Value, Pacific-Basin Finance Journal, Vol. 55, pp. 192-205.

Lim, B., and S. Park, 2019, Insiders' Share Pledges and Stock Price Crash Risk, Korean Journal of Financial Management, Vol. 36 (2), pp. 173-207.

Meng, Q., X. Ni, and J. Zhang, Share Pledging and Corporate Risk-Taking Insights from the Chinese Stock Market, Working Paper, 2019, https://papers.ssrn.com/sol3/papers.cf m?abstract_id=3237881.

Noh, J. H., The Effect of Managerial Share Pledge on the Earnings Management, Working Paper, 2019, http://www.iksa.or.kr/modules/bbs/index.php? code=search_1\&mode=vie w\&id=3148\&page $=28 \& \_$_M_ID $=187 \&$ sfield $=\&$ sword $=$.

Oh, K. W., S. W. Jeong, and S. M. Cha, 2011, The Effect of External Audit on the Cost of Debt of Listed and Private Firms, Korean International Accounting Review, Vol. 38, pp. 143-172.

Ouyang, C., X. Wang, and K. C. Chan, Do Insiders' Share Pledges Affect Bond Yield Spreads? Evidence from an Emerging Market, Working Paper, 2018, https://www.researchgate.net /publication/328470134_Do_Insiders'_Share_Pledges_Affect_Bond_Yield_Spreads_Evi dence_From_an_Emerging_Market.

Park, J. I., and S. I. Kim, 2019, The Effect of Tax Risk and Tax Avoidance on Credit Rating and Cost of Debt, Journal of Taxation and Accounting, Vol. 20 (2), pp. 163-204.

Park, K. S., and C. S. Jung, 2015, A Study on the Effects of Controlling Shareholders' Ownership on the Risk-Taking Behaviors of Savings, Korean Journal of Financial Studies, Vol. 
The Effect of Managerial Share Pledges on the Cost of Debt

44 (5), pp. 829-854.

Park, K. S., and E. J. Lee, 2006, The Role of Investors on the Management and Corporate Governance of Korean Companies, Journal of Money \& Finance, Vol. 20 (2), pp. 73-113. Pittman, J. A., and S. Fortin, 2004, Auditor Choice and the Cost of Debt Capital for Newly Public Firms, Journal of Accounting and Economics, Vol. 37 (1), pp. 113-136.

Puleo, M., M. McDonald, and S. Kozlowski, 2021, Share-Pledging and the Cost of Debt, Accounting \& Finance, Vol. 61, pp. 1047-1079.

Singh, P., Does Pledging of Shares by Controlling Shareholders Always Destroy Firm Value?, Working Paper, 2018, https://papers.ssrn.com/sol3/papers.cfm? abstract_id=2989818.

Wang, Y., and R. K. Chou, 2018, The Impact of Share Pledging Regulations on Stock Trading and Firm Valuation, Journal of Banking \& Finance, Vol. 89, pp. 1-13.

Xu, J., 2021, Relationship Between Controlling Shareholders' Participation in Share Pledging and Accounting Conservatism in China, Australian Accounting Review, Vol. 31, pp. 9-21.

Yang, D. H., S. C. Lee, and J. C. Yoon, 2011, Effect of Disclosure Quality on Cost of Debt, Korean Management Review, Vol. 40 (3), pp. 803-830.

Yu, S. M., 2011, The Effect of Book-tax Difference on Cost of Debt Capital, Korean International Accounting Review, Vol. 36, pp. 225-242.

Zingales, L., 1994, The Value of the Voting Right: A Study of the Milan Stock Exchange Experience, Review of Financial Studies, Vol.7 (1), pp. 125-148. 